\title{
A review of the European planthopper genus Trirhacus and related taxa, with a key to the genera of European Cixiidae (Hemiptera: Fulgoromorpha)
}

\author{
WERNER E. HOLZINGER \\ Oekoteam - Dept. of Faunistics and Animal Ecology, Bergmanngasse 22, A - 8010 Graz, Austria; e-mail: oekoteam@sime.com
}

Key words. Trirhacus, Sphaerocixius gen. n., Neocixius, Nanocixius, Apartus gen. n., Simplicixius gen. n., Sardocixius gen. n., Trirhacus peloponnesiacus sp. n., Cixiidae, taxonomy, morphology

\begin{abstract}
Ten species of Cixiidae, formerly placed in Trirhacus Fieber, 1875, are redescribed and one additional species is described. They belong to seven genera: Trirhacus s. str. with T. setulosus Fieber, 1876 (type species), T. dubiosus Wagner, $1959, T$. biokovensis Dlabola, 1971 and T. peloponnesiacus sp. n., Apartus gen. n. with A. michalki (Wagner, 1948) comb. n. (type species) and A. wagnerianus (Nast, 1965) comb. n., Nanocixius Wagner, 1939 stat. $\mathrm{n}$. with $N$. discrepans (Fieber, 1876) comb. n., Neocixius Wagner, 1939 stat. n. with N. limbatus (Signoret, 1862) comb. n., Sardocixius gen. n. with S. formosissimus (Costa, 1883) comb. n., Simplicixius gen. n. with S. trichophomis (Melichar, 1914) comb. n. and Sphaerocixius Wagner, 1939 stat. n. with S. globuliferus (Wagner, 1939) comb. $\mathrm{n}$. The phylogenetic relationships of these genera to other Cixiidae are briefly discussed and a key to the genera of European Cixiidae is provided.
\end{abstract}

\section{INTRODUCTION}

The genus Trirhacus was described by Fieber (1875) to accommodate a single species from Greece, $T$. setulosus Fieber. Subsequently, two species were added by Costa and Melichar (T. formosissimus Costa, 1883, T. trichophorus Melichar, 1914). Wagner (1939) erected several new subgenera of the genus Cixius Latreille, 1804, among them Nanocixius with C. (N.) discrepans Fieber, 1876, Neocixius with C. (N.) limbatus Signoret, 1862, and Sphaerocixius with C. (S.) globuliferus Wagner, 1939. A few years later he described Neocixius michalki Wagner, 1948, synonymized Nanocixius and Sphaerocixius with Neocixius and raised the latter to generic rank (Wagner, 1948). In 1959 he synonymized Neocixius with Trirhacus (Wagner, 1959). Finally, two more species were described from former Yugoslavia (T. wagnerianus Nast, 1965; T. biokovensis Dlabola, 1971).

As the species from far-eastern Asia, formerly placed in Trirhacus (cf. Vilbaste, 1968), were already re-assigned to Cixius (Tsaur et al., 1991; Holzinger, 1999 b), Trirhacus s. 1. contained ten species from the central and mediterranean parts of Europe at the beginning of this study.

According to Wagner $(1939,1948,1959)$ and Dlabola (1971, 1977, 1980), two groups of characters were used to define the genus. First, the presence of setiferous tubercles not only on the veins of the fore wing, but also on the apical border of the wing between the veins, and second, the reduction of the hind wing between costa and cubitus including the presence of a distinct incision at the end of the cubital vein(s).

The number and arrangement of these setiferous tubercles are very different in different species (see Dlabola, 1977, and Figs 19, 22, 42, 66, 67, 84, 92, 104, 123 and 126). Moreover, these tubercles are also present in Tachycixius Wagner, 1939 and in at least one species of Cixius (see Wagner, 1939; Dlabola, 1980; Remane \& Holzinger, 1998). Thus, multiple independent origins of this character are conceivable, e. g. by the reduction of the apical part of the fore wing and subsequent fusion of the apical end of the veins and their tubercles with the apical margin of the wing. Therefore, I regard this complex of characters as of limited phylogenetic value.

The reduction of the hind wing in Trirhacus s. 1 . is also very likely a convergent character, as the venation of the hind wing is very different within species of Trirhacus $\mathrm{s}$. 1. (see Wagner, 1939, 1948; Nast, 1965 and Figs 24, 43, $60,105,122$ and 137), and as reductive trends in hind wings (although without an incision at the end of the cubital veins) are common in other cixiid taxa, e. g., Cixius spp., Tachycixius spp., Undanara spp., Oliarus spp. and Solonaima spp. (Hoch, 1994; Hoch \& Asche, 1993; Hoch \& Howarth, 1989a, b).

Both groups of characters formerly used to define Trirhacus s. 1. are merely diagnostic, and obviously have a rather limited value for a phylogenetic analysis. On the other hand, the taxa included in Trirhacus s. 1. are morphologically far more heterogenous than those included in many other (monophyletic) cixiid genera. Therefore, a revision of Trirhacus s. 1. based on a phylogenetic analysis is needed.

\section{MATERIAL AND METHODS}

Almost all species of Trirhacus s. 1. are very rare; thus, only few specimens were available for this study.

The material was provided by:

coll. Asche \& Hoch, Museum für Naturkunde, Humboldt Universität Berlin, Germany

coll. Drosopoulos, Agricultural University of Athens, Greece

coll. Holzinger, Ökoteam - Institut für Faunistik und Tierökologie, Graz, Austria 
Dipartimento di Zoologia, Universita Napoli, Italia (DZU Napoli)

Hungarian Natural History Museum, Budapest, Hungary (HNHM Budapest)

Moravian Museum, Brno, Czech Republic (MM Brno)

Museum National d'Histoire Naturelle, Paris, France (MNHN Paris)

Natural History Museum, London, Great Britain (NHM London)

Naturhistorisches Museum, Vienna, Austria (NHM Vienna)

Almost all drawings except those of the structures of the inner female genitalia were made from dried specimens. Inner female genitalia were prepared and stained with "Chlorazol E endocuticular staining" as described by Bourgoin (1993), and drawings were made in distilled water. The morphological terminology is that used in recent taxonomic papers (e. g., Tsaur et al., 1988; Larivière, 1999, in female genitalia Bourgoin, 1993).

\section{MORPHOLOGICAL CHARACTERS OF TAXONOMIC RELEVANCE}

The descriptions of several species of Trirhacus s. 1. are insufficient, at least for revising the genus. Therefore, redescriptions of all species seemed necessary.

The characters used both for species recognition and classification are shown in Figs 8-145. As in other cixiids, important characters can be found in general habitus (proportions and size), head (shape and proportions, keels, coloration), pronotum (shape of caudal margin), mesonotum (shape of keels), fore wings (proportion, venation, colour pattern), hind wings (venation), and in male genitalia (shape of anal segment, genital styles and aedeagus).

External and internal morphological characters of females (see Figs 3, 4, 12, 37-41, 70-73, 82, 83, 90, 91, $93,109-111$ ) have a high value in the phylogenetic resolution of the Cixiidae above the generic level. A comparative study of the female genitalia of Cixiidae will be presented in another paper.

\section{PRELIMINARY PLACEMENT OF TRIRHACUS S. L. WITHIN CIXIIDAE}

The female abdomen of cixiids of several taxa narrows evenly towards the anal segment, with the ovipositor curved dorsad, adjacent to the genital segment (see Fig. 2 ). This configuration is considered to be plesiomorphic within cixiids, as it is also present in other basal Fulgoromorpha taxa. In taxa with the apomorphic state of this character, tergite IX is raised steeply inclined or perpendicular to the body axis and the abdomen is therefore more or less truncate, with the ovipositor either curved dorsad, but not adjacent, or directed more or less straight caudad (see Figs 1, 3, 4). At the moment, there is no evidence for a multiple origin of this configuration. Therefore, all cixiids with a truncate female abdomen are likely to be monophyletic. All species of Trirhacus s. 1. belong to this taxon.

In many cixiids with a truncate female abdomen, wax plates are present on tergite IX. It seems probable, that species with wax plates have evolved from species with a truncate abdomen. With regard to their ultrastructure, at least two different types of wax plates are present in adult cixiids (see Holzinger et al., 2002).

Within Trirhacus s. 1., at least seven species do not have a wax plate, whereas two species belong to the group bearing a wax plate with "Cixius-like" wax pores on tergite IX. If the hypothesis presented above is true, it is evident, that Trirhacus s. 1. is polyphyletic.

\section{TAXONOMIC CONSEQUENCES}

In contrast to all other species of Trirhacus s. 1., females of Neocixius michalki Wagner, 1948 and Trirhacus wagnerianus Nast, 1965 have a wax plate at the end of the abdomen. This wax plate is evenly, covered with a regular pattern of uniform wax pores (Fig. 5, 6), and is divided medially by a flat, dorsoventral keel. The pattern of wax pores is similar to that in other Cixiini (Cixius nervosus, Cixius similis, Tachycixius pilosus, Notocixius magellanicus) and significantly different from that of Pentastirini (see Holzinger et al., 2002). The wax plate is smaller as in Cixius and Tachycixius, and the transition between the plate and the lateral abdomen is not more or less at a right-angle (as in Cixius and Tachycixius, see Fig. 1), but smoothly rounded (see Fig. 10).

This special configuration might represent a very primitive type of wax plate, where the tergite IX is still rounded laterally as in taxa without a wax plate. In this case the median keel can be interpreted as a relict of the melting of the lateral borders of the tergites between the anal segment and the ovipositor. Following this scenario, in "higher Cixiini" the wax plate widened laterally, developed a right-angled border, and the median keel vanished completely.

Several character states of the male genitalia of these two species are plesiomorphic: The shape of the anal segment (almost symmetrical, with a ventral process forming two small lobes) and of the aedeagus (phallosoma tubular, without keels, apical part comparatively simple and only slightly bent). In contrast, the special shape of the genital style with a longitudinal ridge on the stem, orientated vertically towards the expanded apical part of the style (see Figs 13, 14), is a character state that should be interpreted as apomorphic. This longitudinal ridge obviously helps the male to remain fixed to the female during mating, as it is clamped between gonoplac and gonapophysis VIII during copulation (see Fig. 10).

Based on the above characters, it is evident, that Neocixius michalki Wagner, 1948 and Trirhacus wagnerianus Nast, 1965 represent a monophyletic taxon apart from other cixiid genera; therefore a new genus, Apartus gen. nov. (type species: Neocixius michalki Wagner, 1948), is erected to accomodate these species.

Trirhacus formosissimus Costa, 1883 is easily distinguishable from other cixiids by the presence of black elevations along the veins at the apex of the hind wing (Figs 66,67 ), a character state which is most likely to be apomorphic. In addition, the special configuration of the frons (reduction of the keel on the junction between frons 

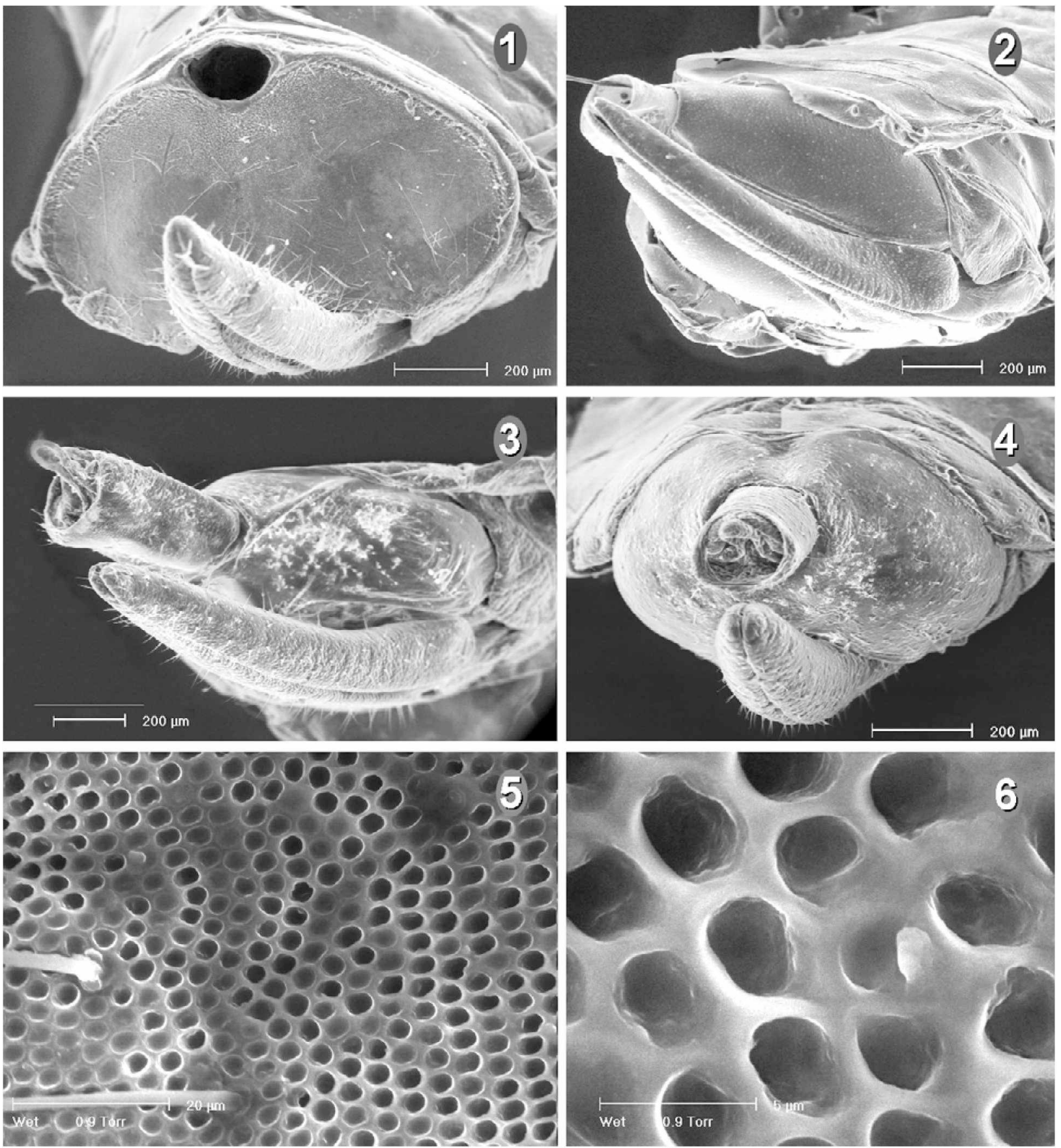

Figs 1-6. Female abdomen. 1 - Tachycixius pilosus (Olivier, 1791), female abdomen with wax gland area, anal segment removed; 2 - Bothriocera signoreti Stăl, 1864; 3 - Sphaerocixius globuliferus (Wagner, 1939); 4 - Nanocixius discrepans (Fieber, 1876); 5 Apartus michalki (Wagner, 1948), wax gland area; 6 - Apartus michalki (Wagner, 1948), wax glands at higher magnification. All SEM pictures by E. Stabentheiner, Graz.

and vertex, weakening of the median keel, lateral elevation of the lateral keels, black coloration; see Figs 61, 62, 64) possibly evolved only once. As it is not possible to place this species in any other genus, a new genus, Sardocixius gen. $\mathbf{n}$. is erected for it.

For three species of Trirhacus s. 1., Cixius (Sphaerocixius) globuliferus Wagner, 1939, Cixius (Nanocixius) discrepans Fieber, 1876 and Cixius (Neocixius) limbatus Signoret, 1862, Wagner (1939) described new subgenera within Cixius. In all those species, females have a rounded tergite IX without a wax plate (Figs 4, 38-41, 90,91 ). If the hypothesis about the evolution of wax plates is correct and if a secondary reduction of these plates has not occured (as there are no indications of a reduction), placing these three species and subgenera within Cixius is not correct.

Currently there is no evidence in support of at least a provisional integration of these taxa into other cixiid genera. Therefore, all three subgenera are reinstated as separate genera. 


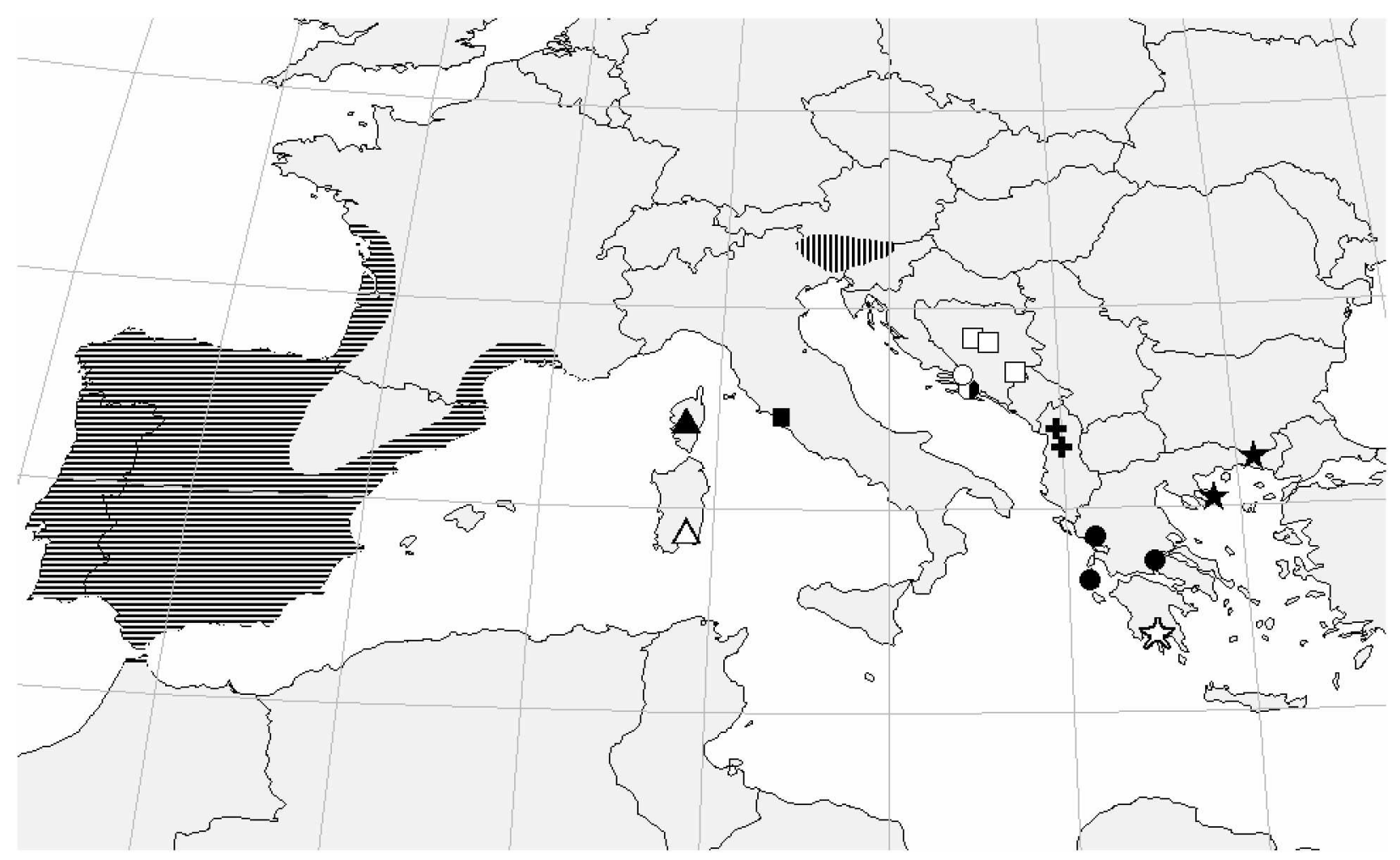

Fig. 7. Localities of species formerly placed in Trirhacus s. 1. Nanocixius discrepans (horizontal line and black full square), Neocixius limbatus (black triangle), Sardocixius formosissimus (white triangle), Apartus michalki (vertical line), A. wagnerianus (white squares), Sphaerocixius globuliferus (black crosses), Trirhacus biokovensis (white circle), T. dubiosus (half-black circle), T. setulosus (black circles), T. peloponnesiacus (white asterisk), Simplicixius trichophorus (black asterisks).

Autapomorphies of Sphaerocixius Wagner, 1939 stat. n. with Sphaerocixius globuliferus (Wagner, 1939) comb. $\mathrm{n}$. are the unique structures both in the male anal segment (apical ventral process almost completely reduced, new formation of a basal globular process; Fig. 94) and in the aedeagus (special shape of the apical part and in the processes of the phallosoma, see Figs 97-99).

Autapomorphies of Nanocixius stat. $\mathbf{n}$. are the reduction of the median keel on the clypeus and the presence of a longitudinal ridge on the stem of the genital style (Wagner, 1939, see Figs 25, 31). The latter is similar to, but following this interpretation - convergent with the configuration in Apartus.

Neocixius stat. $\mathbf{n}$. is a taxon endemic to Corsica. It is easily determinable by the colour pattern on the head and fore wings. The diagnostic characters mentioned by Wagner (1939) - anal segment simple, three movable spines at the distal end of the phallosoma, phallosoma without dorsal keels - are known from several other cixiid taxa, too, and are therefore of little phylogenetic value.

Trirhacus trichophorus Melichar, 1914, is a large species with very simple male genitalia. The phallosoma is tubular without keels, only a lateral widening is visible on its right side. One movable spine is present on each side. The apical part of the aedeagus is strongly s-shaped in dorsal view. The genital style is very simple. The anal segment is very long and slender with an almost symmetrical ventral process. In females, the abdomen is shaped like an inverse "V", similar to the situation in Sphaerocixius (Fig. 3) and distinctively different from Nanocixius and Neocixius. Again, all characters are excellent from a diagnostic point of view, but either have little phylogenetic value (male genitalia) or are currently not polarisable (female genitalia). As evidence in support of integrating this species in another cixiid genus is not available, provisionally a new genus, Simplicixius gen. n., is erected for this species.

Three previously known and one new species of Trirhacus s. 1., all occuring on the Balkan peninsula (see Fig. 7), have several characters that are conspicuously similar and are placed provisionally in Trirhacus s. str.: T. setulosus Fieber, 1876 (type species), $T$. dubiosus Wagner, 1959, T. biokovensis Dlabola, 1971 and T. peloponnesiacus $\mathrm{sp} . \mathrm{n}$. The unifying characters are the presence of a ventral process or crest on the phallosoma, a dorsolateral widening on the left side of the phallosoma, a subapical process on the apical part of the aedeagus, a short, asymmetrical anal segment and comparatively short fore wings.

It must be kept in mind, that all these characters are also found in other cixiid taxa. Thus, they could equally be synapomorphies, symplesiomorphies or convergences and are not strong evidence for the monophyly of Trirhacus s. str.

The phylogenetic relationships of all these genera and to other cixiid taxa are unknown at present and a compre- 
hensive phylogenetic framework of the Cixiini and Cixiidae is awaited.

A key to the genera of the family Cixiidae in Europe not including the Balearic and Azorean Is. - is given below.

\section{KEY TO THE EUROPEAN GENERA OF CIXIIDAE}

1 Mesonotum with five keels $\ldots \ldots \ldots \ldots \ldots \ldots \ldots, 12$

- Mesonotum with three keels . . ............. 2

2 Hind tibia without lateral spines. Abdomen in female narrowing towards anal tube, ovipositor adjacent ....... 3

- Hind tibia with 1-3 lateral spines. Abdomen in female truncate, with or without wax plate $\ldots \ldots \ldots \ldots \ldots \ldots 5$

3 Median and lateral keels of postclypeus distinct, produced . ....................... Myndus Stål, 1862

- Median and lateral keels of postclypeus obsolete ..... 4

4 Median keel on vertex smooth. Short and stout species .... .................. Trigonocranus Fieber, 1875

- Median keel on vertex distinct. Long and slender species .. Duilius, Stål, 1858

5(2)Area of apical veins in fore wings bearing large black elevations (Figs 66, 67) . . . . . Sardocixius Holzinger, gen. $\mathrm{n}$.

Area of apical veins in fore wings different ........6 6

6 Apical margin of hind wing with a distinct incision at the end of cubital veins (Fig. 43) $\ldots \ldots \ldots \ldots \ldots \ldots 7$

- Apical margin of hind wing without incision. Abdomen of females bearing an undivided wax plate $\ldots \ldots \ldots \ldots 11$

7 Face (except keels) and genae dark brown or black in upper part and light brown ventrally $\ldots \ldots \ldots \ldots \ldots .8$

- Face and genae more or less uniform brownish, keels often lighter $\ldots \ldots \ldots \ldots \ldots \ldots \ldots \ldots \ldots \ldots$

8 Phallosoma with three subapical movable spines. Female abdomen capsular, rounded (Fig. 4) ...............

Neocixius Wagner, 1939

- Phallosoma with two subapical movable spines. Female abdomen truncate, shaped as an inverse "V" (Fig. 3) .... . Simplicixius Holzinger, gen. $\mathrm{n}$.

9(7) Median keel on postclypeus obsolete ventrally. Phallosoma without a rigid ventral process, but with three subapical spines. Small species, of max. $4.4 \mathrm{~mm}$, 우 o max. $4.7 \mathrm{~mm}$

Nanocixius Wagner, 1939

- Median keel on postclypeus distinct. Total body length at least $4.5 \mathrm{~mm}$, usually larger $\ldots \ldots \ldots \ldots \ldots$

9 Phallosoma with two subapical spines on the right and two on the left side. Females with a wax plate divided by a median keel ............. Apartus Holzinger, gen. $\mathrm{n}$

Arrangement of subapical spines of phallosoma different. Females lack a wax plate $\ldots \ldots \ldots \ldots \ldots \ldots \ldots . . \ldots 10$

10 Male anal tube apically without lobes, but basally with a bulbous widening. End of female abdomen truncate, shaped like an inverse "V" (Fig. 5). Face dark brown, light spots present only on the lateral parts of the frontoclypeal suture

Sphaerocixius Wagner, 1939

- Anal tube apically asymmetrical, with ventrocephalad lobes, basally without widening. Female abdomen capsular, roundish. Face more or less uniform brownish

Trirhacus Fieber, 1875

11(6) Apical margin of fore wings usually without granulae between apical veins. If granulae between veins present, then a large bulging keel is present on the ventral side of the phallosoma ................. Cixius Latreille, 1804

- Apical margin of fore wings with hairy granulae between the apical veins as well as along the veins

Tachycixius Wagner, 1939
12(1) Junction between frons and vertex lacks a keel. Median carina of frons only visible by its paler colour. Postclypeus without keel. (monotypic genus; only male known, small species - body length $4 \mathrm{~mm}) \ldots \ldots \ldots \ldots \ldots \ldots$

Mesoliarus Matsumura, 1910

Distinct keel on junction between frons and vertex ... 13

13 Median carina of frons not forked Hyalesthes Signoret, 1865

- Median carina on frons forked above . . ......... 14

14 Median carina on frons forked almost half the length of the frons . . . . . . . . . . . Pseudoliarus Haupt, 1927

- Median carina on frons forked in upper third of the frons 15

15 At least 12 apical teeth on first tarsomere of hind tarsi (except subgenus Polania Emeljanov, 1995: only 9 apical teeth) $\ldots \ldots \ldots \ldots \ldots$ Pentastiridius Kirschbaum, 1868

- Not more than 10 apical teeth on first tarsomore of hind tarsi

16 Fore carina of posterior compartment of vertex produced forward strongly, forming an acute angle. Ovipositor long and rigid ............ Eumecurus Emeljanov, 1971

- Fore carina of posterior compartment of vertex produced forward, forming an obtuse or rectangular angle. Ovipositor reduced: short and feeble . . . . . . . . . . . . 17

17 Genital styles of males without inner recurrent process, only simple process present. First tarsomere of hind tarsi with 7-8 setae, without platellae. Second tarsomere with 8-9 setae and 5-7 platellae. Index vertex lenght: width 1-1.5. Total length min. $8 \mathrm{~mm}$... Pentastira Kirschbaum, 1868

- Genital styles with inner recurrent process. Vertex distinctly broader (between eyes) than (medially) long . . . . . 18

18 First segment of hind tarsi with long platellae with a toothlike pedestal ........... Reptalus Emeljanov, 1971

- First segment of hind tarsi with blunt platellae, without tooth-like pedestal .......... Setapius Dlabola, 1988

\section{DESCRIPTIONS OF GENERA AND SPECIES}

\section{Apartus gen. $\mathrm{n}$.}

Type species. Neocixius michalki Wagner, 1948

Included species. Apartus michalki (Wagner, 1948) comb. n., Apartus wagnerianus (Nast, 1965) comb. n.

Etymology. The name is derived from the name of the grant financing this study, APART. Gender: masculine.

Diagnosis. Oval-shaped species. Female abdomen truncate, bearing a distinct, dorsoventrally divided wax plate. Male phallosoma tubular, dorsally with a distinct process on the right side. Two movable subapical spines are present on each side. Genital style with a longitudinal ridge on the stem, orientated vertically to the expanded apical part of the style. Anal tube in males dorsoventrally flattened, ventral process apically forming two small, slightly asymmetrical lobes directed ventrocephalad (Fig. 12). Radius and media in hind wings apically forked.

Apartus michalki (Wagner, 1948) comb. n. (Figs 5, 6, 8-12, 22)

Neocixius michalki Wagner, 1948: 85

Trirhacus michalki Wagner, 1959: 586

Material. Several males and females from coll. Holzinger, Graz.

Description. (See also Holzinger 1999 a) Total length of male $4.8-5.3 \mathrm{~mm}$, of female $5.3-5.8 \mathrm{~mm}$. 


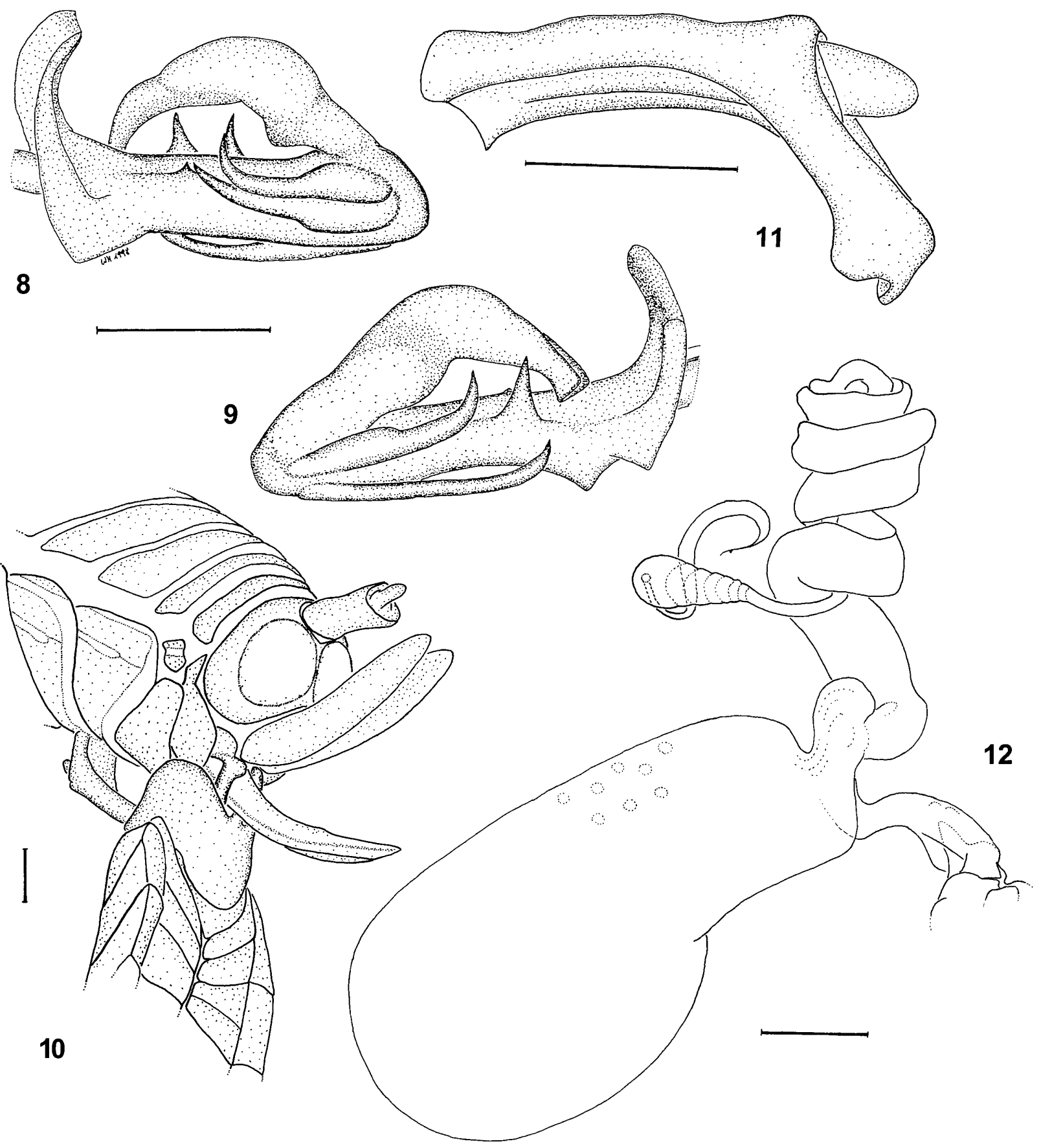

Figs 8-12. Apartus michalki (Wagner, 1948). 8-9 - aedeagus (from Holzinger, 1999a); 10 - mating position (laterocaudal view of female, lateroventral of male); 11 - male anal segment; 12 - ductus receptaculi and bursa copulatrix. Scale bar $=0.25 \mathrm{~mm}$.

Face, vertex, pronotum and mesonotum more or less brownish. Fore wings hyaline with characteristic dark markings (Fig. 22).

Phallosoma tubular, dorsally with a smaller triangular process on the left and a larger triangular process on the right side. Two movable subapical spines are present laterally on each side (Figs 8, 9).

Female abdomen truncate with a distinct wax plate, divided in two parts by a median keel. Ductus receptaculi with six windings (Fig. 12).
Distribution and ecology. Endemic in the Southern Lime Alps (Austria, Italy, Slovenia), living in thermophilic pine forests. Adults can be found in spring (Holzinger 1999 a).

\section{Apartus wagnerianus (Nast, 1965) comb. n. (Figs} 13-21, 23)

Trirhacus wagnerianus Nast, 1965: 185 (Figs 4-7)

Material studied. Holotype $\hat{o}$, labelled (red label) "Holo- / typus", "(handwritten) Trirhacus / setulosus / Fieb. / (printed) det. Horvath", "(handwritten) Trirhacus / setulosus", "Bosnia / Trebevic / Horváth", "(handwritten) 

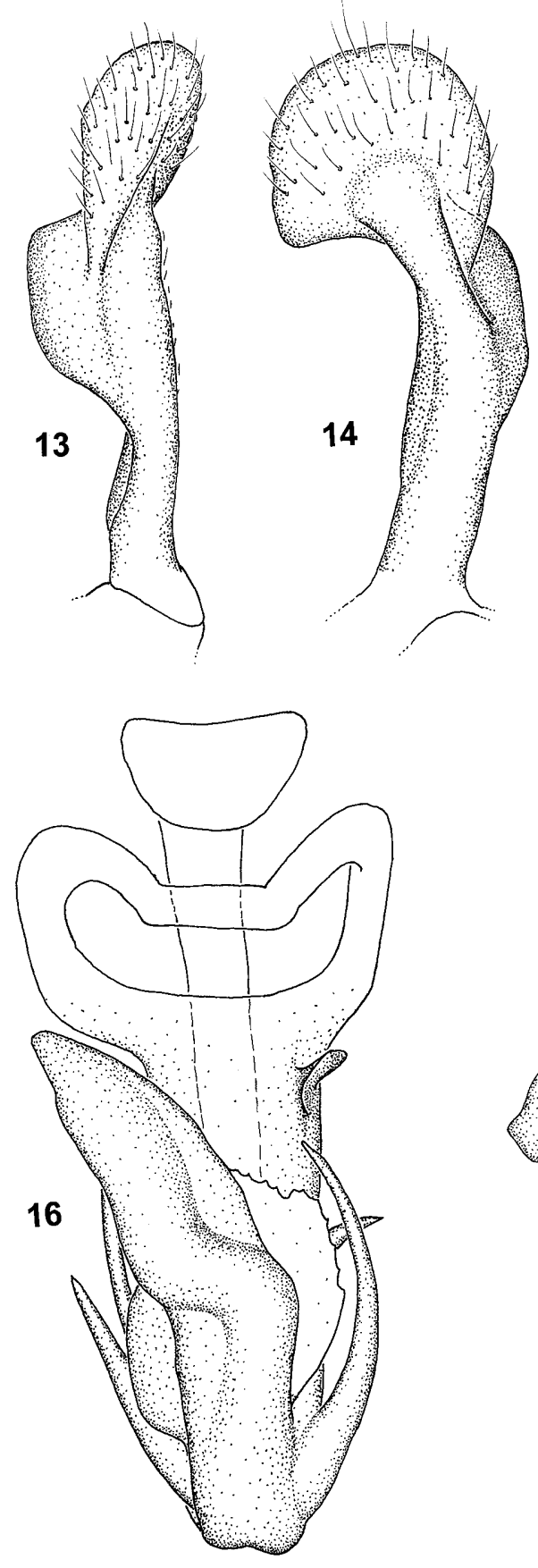

Figs 13-18. Apartus wagnerianus (Nast, 1965), holotype male. 13 - left genital style from below; 14 - right genital style, maximum view; 15 - anal segment, lateral view; $16-18-$ aedeagus. Scale bar $=0.25 \mathrm{~mm}$.

Trirhacus đ̊ / wagnerianus / sp. n., Nast, 1962", "Nast 2", in coll. NHM Budapest.

1 o , 1 \& both labelled "Jugoslavia, 2.6.67 / Hercegovina 9/67 / Sutjeska, Perucica / lgt. Pavel Lauterer", "Collectio / P. Lauterer / Mor. museum, Brno", in coll. MM Brno.

Description. (See also Nast, 1965) Total length of male 5.7-6.0 mm, of female $6.0-6.1 \mathrm{~mm}$.

Face, vertex, pronotum and mesonotum more or less light-brown, keels whitish. Fore wings hyaline, with dark markings as shown in Fig. 19.
Phallosoma tubular, dorsally with a distinct subapical widening on the left side and a basal lobe on the right side. In addition, two movable subapical spines are present on each side.

The female genitalia of the only female studied are very similar to $A$. michalki (wax plate divided by median keel, ductus receptaculi with six windings; with minor differences in the number and size of the sclerotisized plates in the wall of the vagina).

Distribution and ecology. Known only from the type locality (Bosnia, Zvijezda Mts., Trebevic) and from Sutjeska National Park in the very south of Hercegovina. Ecology unknown. 


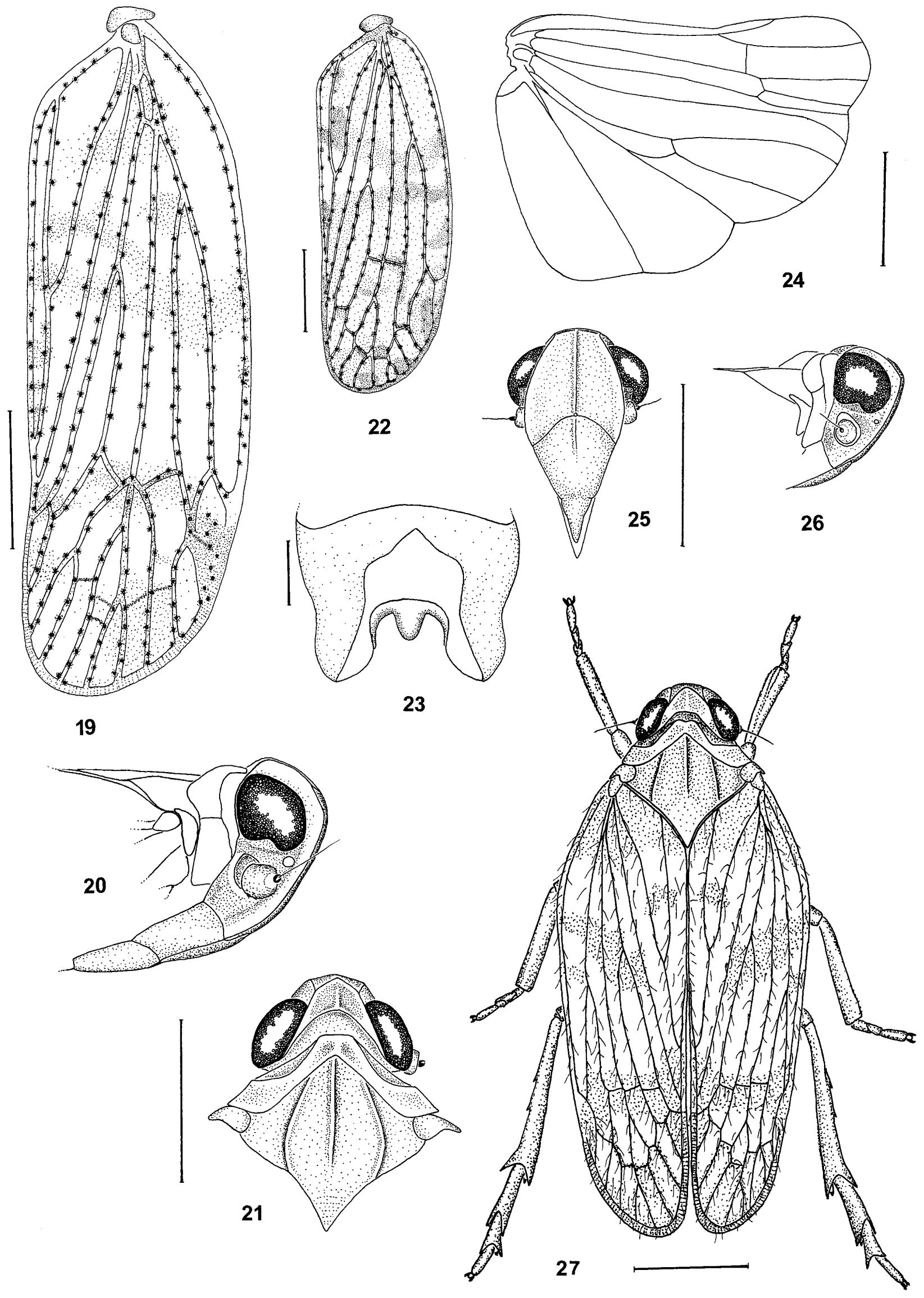



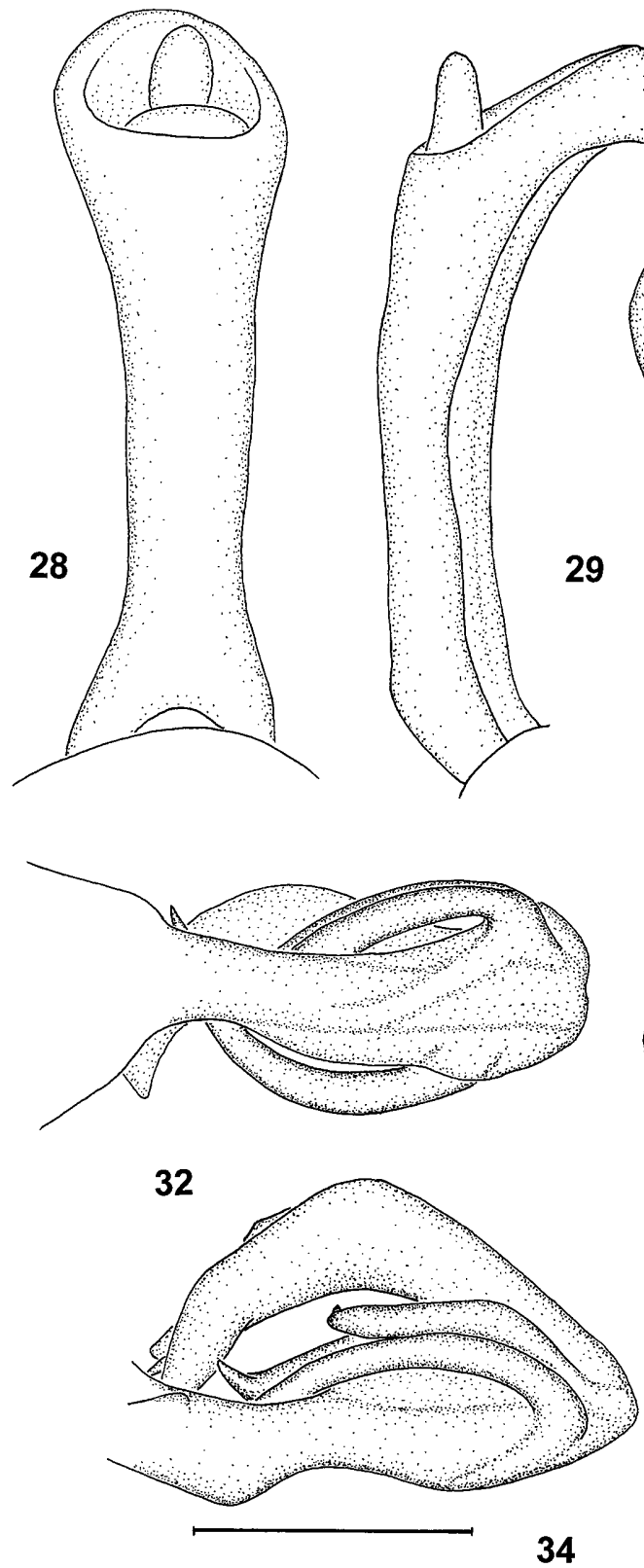

34

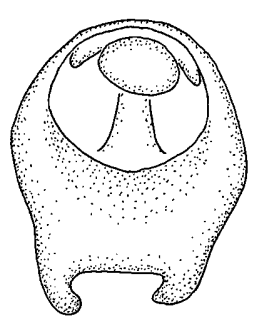

30
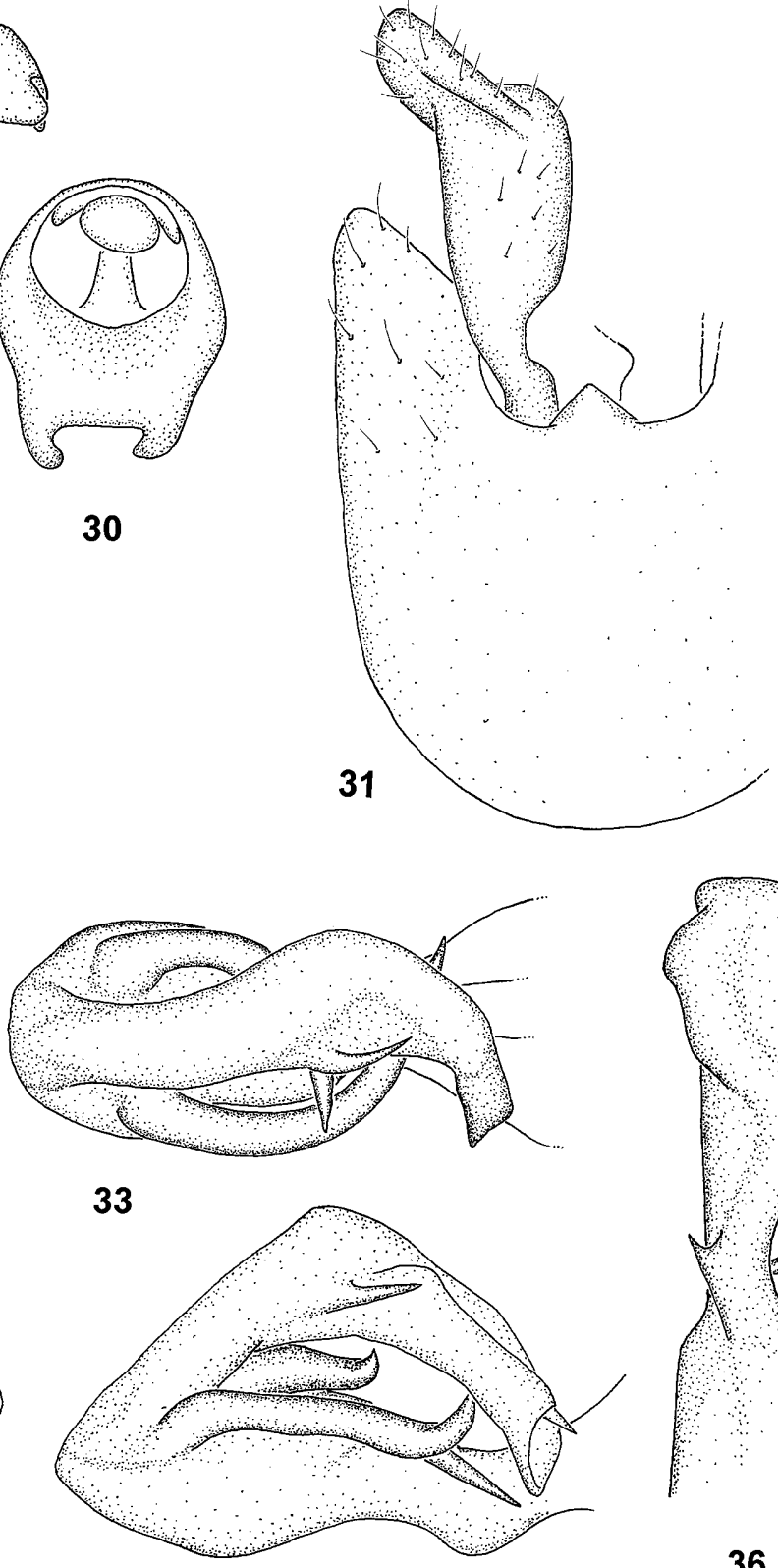

35

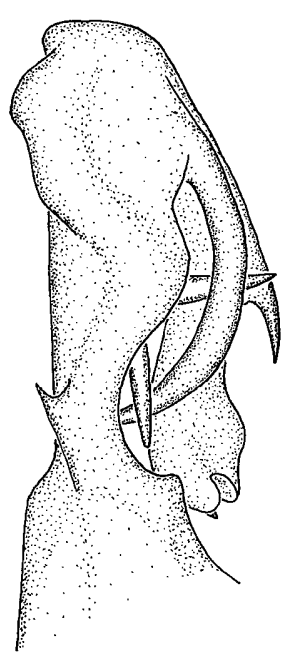

36

Figs 28-36. Neocixius discrepans (Fieber, 1876), male. 28-30 - anal segment, dorsal, lateral and caudal views; 31 - genital segment and left genital style; $32-35$ - aedeagus; 36 - aedeagus of another specimen, ventrolateral view. Scale bar $=0.25 \mathrm{~mm}$.

\section{Nanocixius Wagner, 1939: 94 stat. n.}

Type species. Cixius discrepans Fieber, 1876

Included species. Currently monospecific.

Diagnosis. Small and slender species. Median keel of face vanishing on the ventral part of the postclypeus. Phallosoma comparatively simple, tubular, with one movable subapical spine on the right and two on the left side. Apical part of aedeagus bearing a slender tooth on the right side. Anal tube in males long and slender, ventral process apically with two very small lobes directed ventrocephalad. Genital style with a longitudinal ridge on the stem, orientated vertically to the expanded apical part of the style. Female abdomen apically evenly rounded, capsular-truncate, without wax-plate.

Distribution. Western mediterranean; known from Portugal, Spain, southern and southwestern France, central Italy and Morocco.

Fig. 22. Apartus michalki (Wagner, 1948), fore wing (from Holzinger, 1999a). Scale bar $=1 \mathrm{~mm}$.

Fig. 23. Apartus wagnerianus (Nast, 1965), genital segment, dorsal view. Scale bar $=0.2 \mathrm{~mm}$.

Figs 24-27. Neocixius discrepans (Fieber, 1876), female. 24 - hind wing; 25-26 - head, frontal and lateral view; 27 - habitus. Scale bar $=1 \mathrm{~mm}$. 

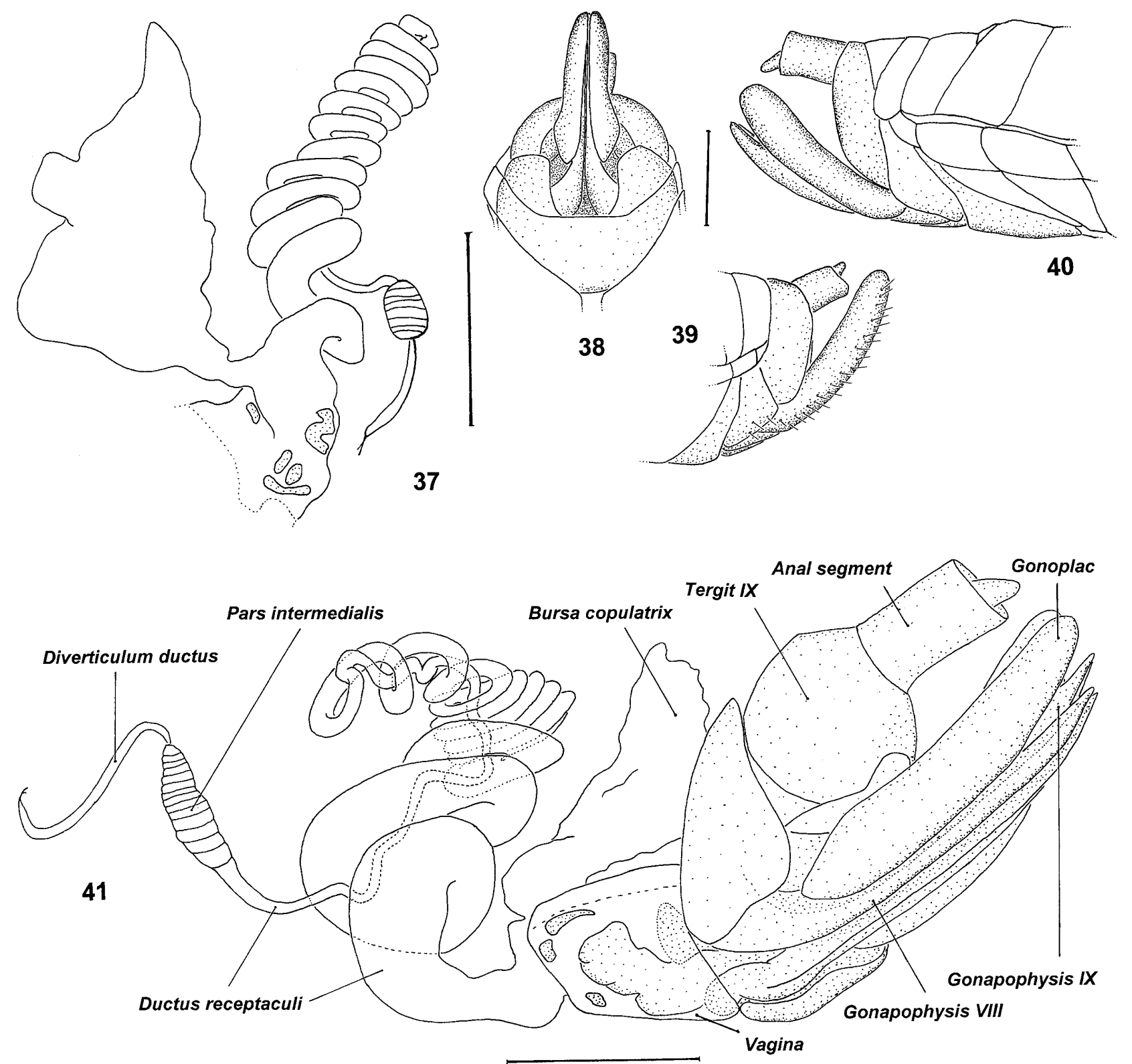

Figs 37-39. Neocixius discrepans (Fieber, 1876), female. 37 - inner genitalia; 38 - abdomen, ventral view (setae omitted); 39 abdomen, lateral view. Scale $b a r=0.5 \mathrm{~mm}$.

\section{Nanocixius discrepans (Fieber, 1876) comb. n. (Figs 24-39)}

Cixius discrepans Fieber, 1876: 168

Cixius (Nanocixius) discrepans: Wagner, 1939: 94

Neocixius discrepans Wagner, 1948: 85

Trirhacus discrepans Wagner, 1959: 586

Material studied. Several males and females from various collections.

Description. (See also Wagner, 1939) Total length of males 3.8-4.4 mm, of females $4.4-4.7 \mathrm{~mm}$.

Face, vertex, pro- and mesonotum brownish, keels lighter. Fore wings hyaline or yellowish-brown, with or without distinct dark bands and markings.

Phallosoma tubular, in some specimens with one or two small teeth ventrally. One movable subapical spine on the right and two on the left side. Apical part of aedeagus bearing a slender tooth on the right side.

Female abdomen apically truncate, without wax-plate. Ductus ejaculatorius with twelve windings. Receptaculum seminis very short.

Distribution and ecology. Described from Italy, recorded there from Lazio (e. g. Castellani, 1953). Widespread in thermophilic forests of southern and southwestern France, Spain and Portugal (e. g. Ribaut, 1958, and unpublished records in several Museums). Also recorded from Tanger, Morocco (Melichar, 1907). Adults can be found in early spring.

\section{Neocixius Wagner, 1939: 94 stat. n./stat. resurrect.*}

Type species. Cixius limbatus Signoret, 1862

Included species. Currently monospecific. 


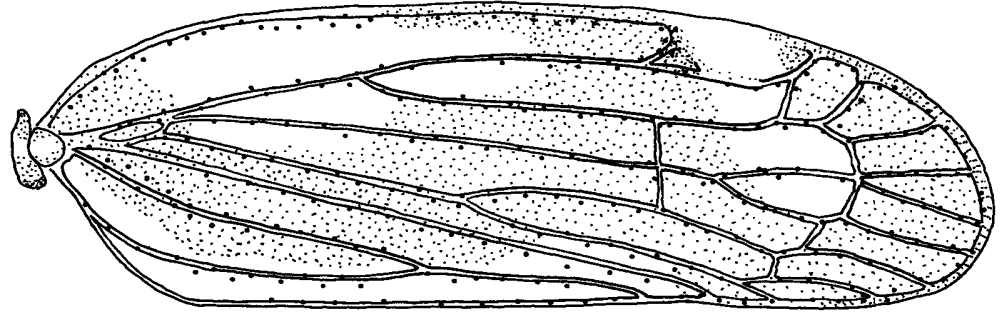

42
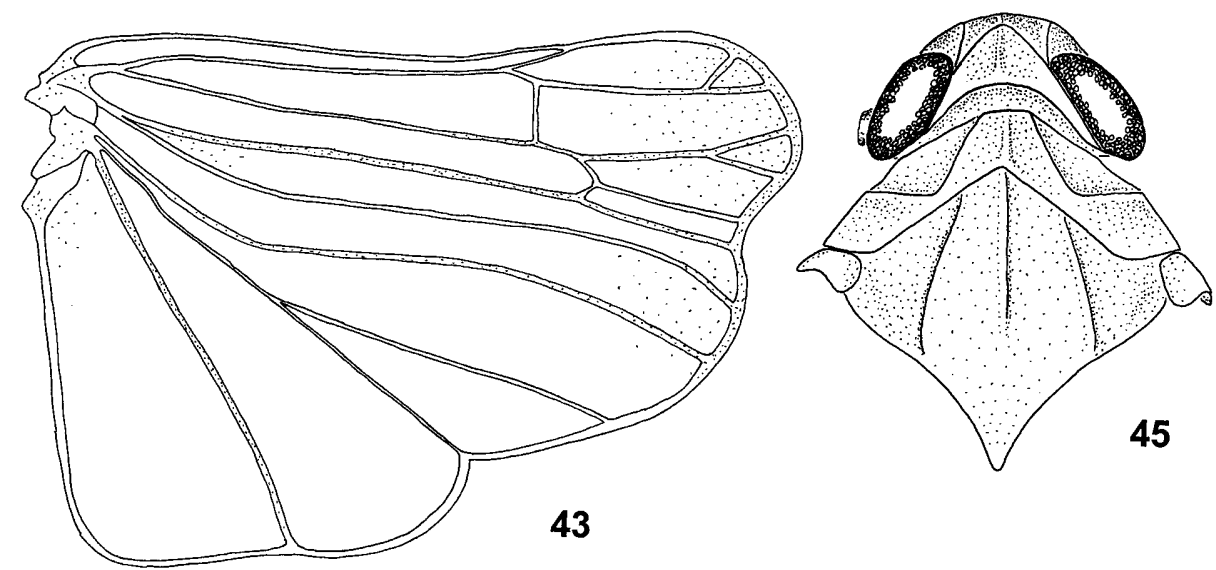

45
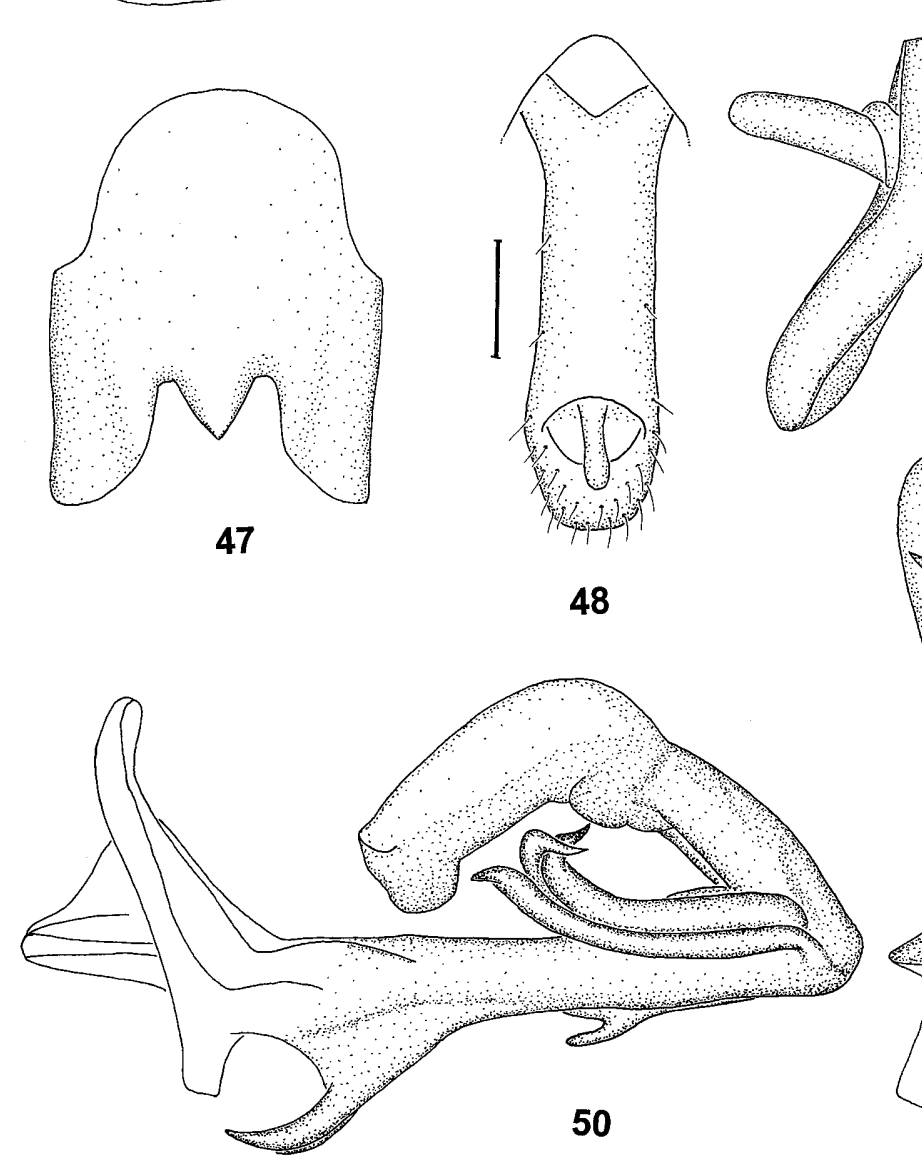

48

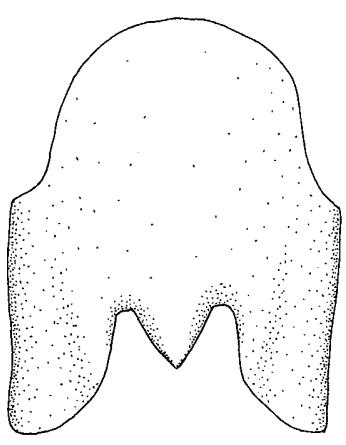

47

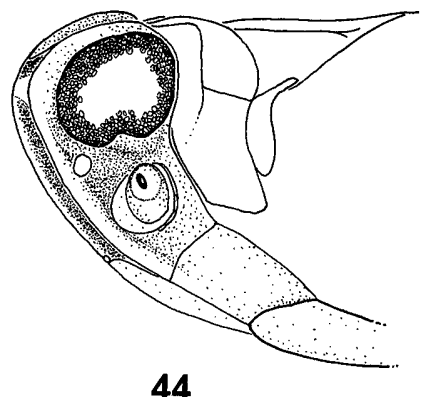

44

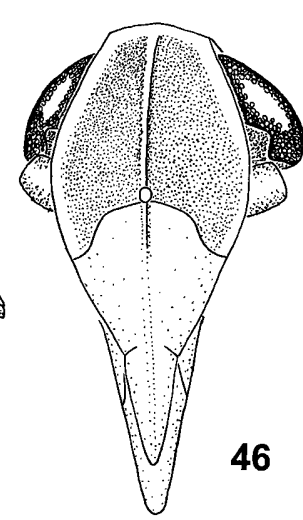

46

Figs 42-46. Neocixius limbatus (Signoret, 1862). 42 - fore wing; 43 - hind wing; 44 - head, lateral view; 45 - head and thorax, dorsal view; $46-$ head, frontal view. Scale bar $=1 \mathrm{~mm}$.

Figs 47-52. Neocixius limbatus (Signoret, 1862), male. 47 - genital segment, ventral view; 48 - anal tube, dorsal view; 49 - anal tube, lateral view; $50-52$ - aedeagus. Scale bar $=0.2 \mathrm{~mm}$. 

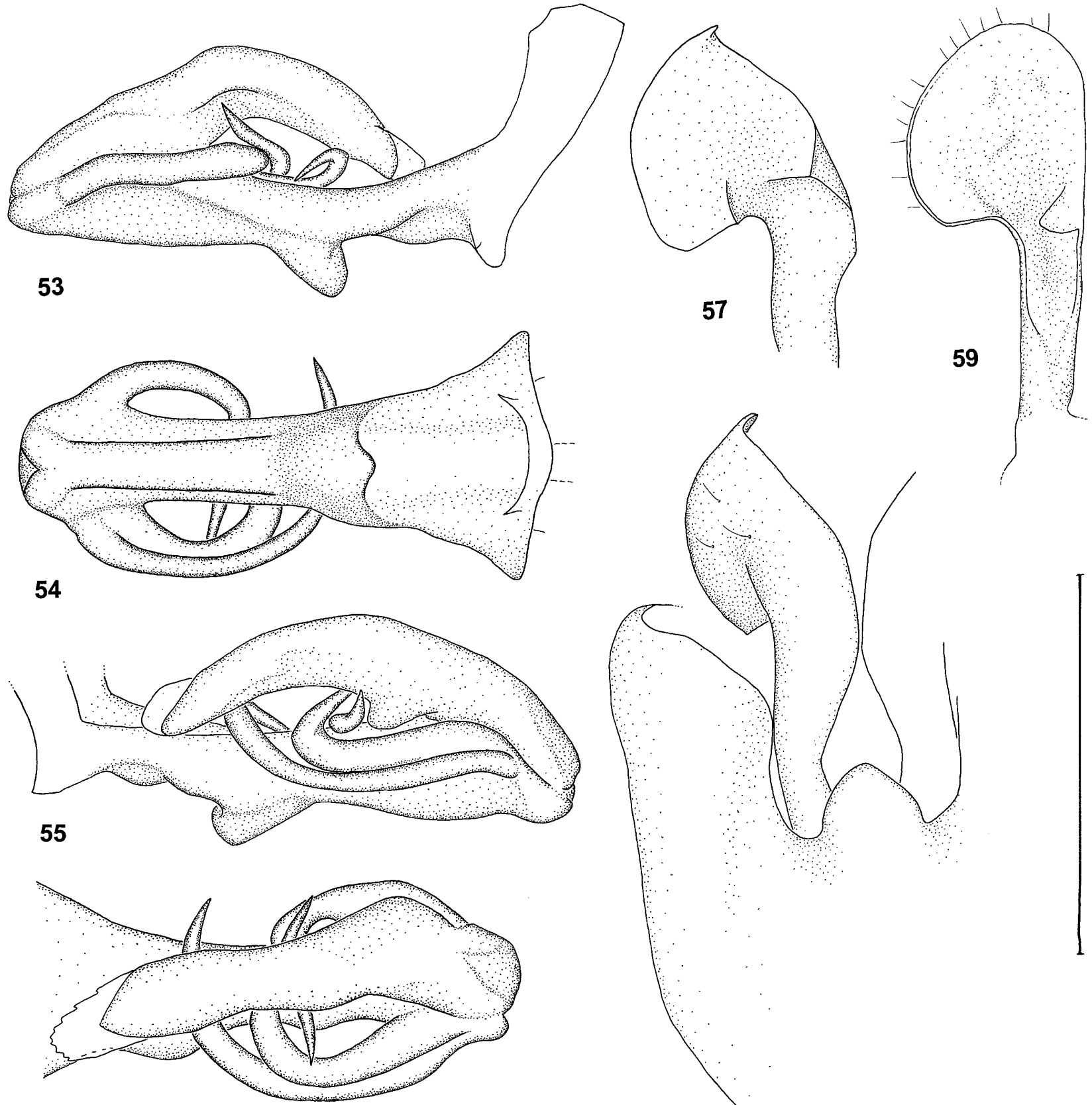

56

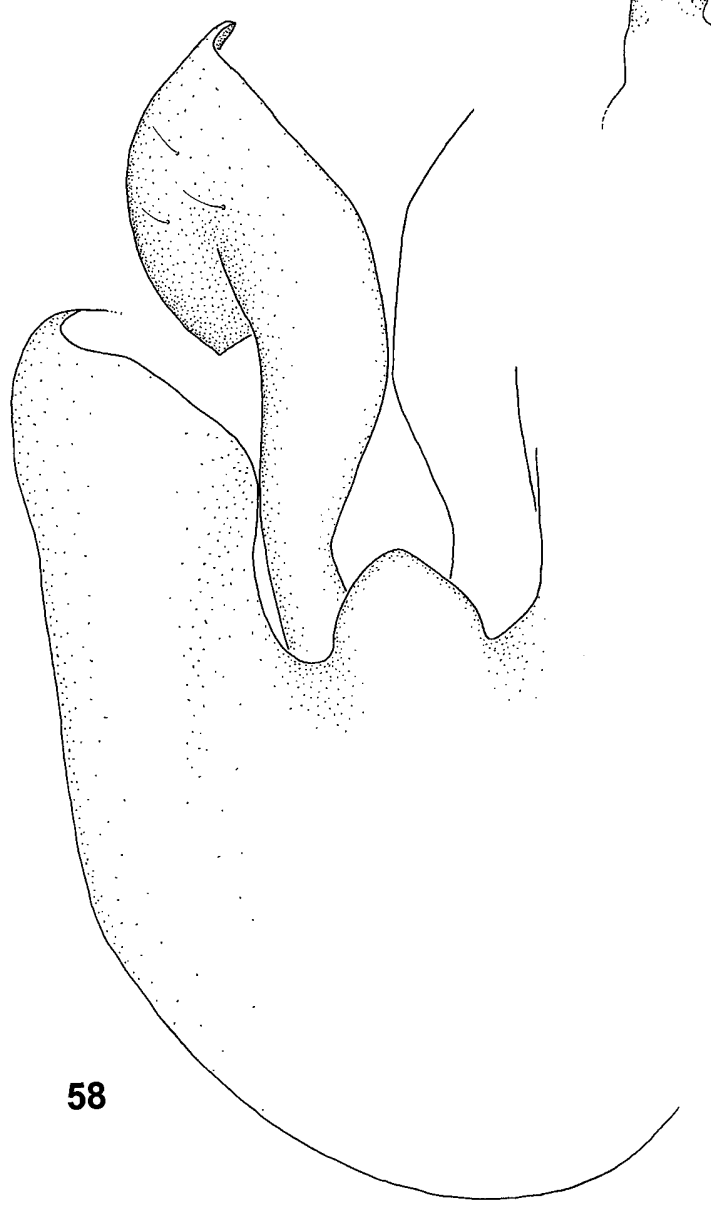

Figs 53-58. Sardocixius formosissimus (Costa, 1883), male. 53-56 - aedeagus; 57 - right genital style, inner maximum view; 58 left genital style and genital segment, ventral view. Scale bar $=0.5 \mathrm{~mm}$.

Fig. 59. Neocixius limbatus (Signoret, 1862), right genital style, inner maximum view. Scale bar $=0.5 \mathrm{~mm}$

Diagnosis. Basal part of phallosoma with a rigid ventral bifurcate process (as in Trirhacus). Anal tube in males long and slender, ventral process smoothly rounded at apex. Genital styles spoon-shaped, simple. End of abdomen of females capsular-truncate. Radius and media of the hind wing forked apically.

Distribution. Corsica.

*Note. Neocixius Wagner, 1939 was treated as genus by Ribaut (1958) and Servadei (1967). This change of status was not done according to the Nomenclature code, and subsequent authors (Wagner, 1959, Nast, 1965, 1972, 1987, D'Urso, 1995) did not accept this "new" status. Therefore, this change might be considered as proposing a new status or as restoration of an already published status.

Neocixius limbatus (Signoret, 1862) comb. n. (Figs 40-52, 59)

Cixius limbatus Signoret, 1862: 378 
Cixius (Neocixius) limbatus Wagner 1939: 94 (Figs 6-10) Trirhacus limbatus Wagner 1959: 586

Material studied. Holotype $\delta$, labelled "(handwritten) Corsica / (printed) Coll. Signoret", "(handwritten) limbatus / (printed) det. Signoret", "Zeichnung / Nr. 160 / W Wagner", (red label) "Holotype", in coll. NHM Vienna.

1 o labelled "Bocognano / Corsica / G.C.C.", "Brit. Mus. / 1926 - 171", 1 \& labelled "Bocognano / Corsica / G.C. .", "Champion / Coll. B. M. / 1927 - 409", both in coll. NHM London.

Description. (See also Wagner, 1939) Total length of male $5.2-5.4 \mathrm{~mm}$, of female $5.7 \mathrm{~mm}$.

Vertex and frons dark brown, keels lighter. Upper (dorsal) part of genae dark brown, ventral part light-brown. Pronotum and mesonotum medially light brown, laterally darker. Fore wings with a characteristic dark pattern (Fig 42).

Ventral part of phallosoma with a large basal ridge bearing two slender processes and a small median process. Two long and slender curved movable subapical spines on the left side, and one on the right side.

Female abdomen truncate, evenly rounded, without wax plate. Inner genitalia see Fig. 41.

Distribution and ecology. Endemic to Corsica, ecology unknown.

\section{Sardocixius gen. $n$.}

Type species. Trirhacus formosissimus Costa, 1883

Included species. Currently monospecific.

Etymology. The only known species is restricted to Sardinia. Gender: masculine.

Diagnosis. Unmistakable taxon. Apical veins in fore wings elevated, with distinct dark markings. Cubitus in the hind wing not forked. Junction between frons and vertex smooth, without distinct keel. Median keel of frons very weak, disappearing at the junction with the vertex. Lateral keels of vertex and postclypeus laterally strongly produced. Postclypeus swollen.

Sardocixius formosissimus (Costa, 1883) comb. n. (Figs 53-58, 60-73)

Trirhacus formosissimus Costa, 1883: 339

Material studied. Lectotype (here designated) $\delta$, labelled " $\delta$ ", (red label) "Trirhacus / formosissimus / A. Costa, 1883", (red label) "Lectotypus / W. Holzinger design." in DZU Napoli.

1 specimen with abdomen missing, labelled "(handwritten) Trirhacus / formosissimus", in coll. DZU Napoli; 1 , labelled "Sardinia", in coll. Puton, MNHN Paris.

Description. (See also Costa, 1888) Total length of male $5.6 \mathrm{~mm}$, of female $6,0 \mathrm{~mm}$

Upper part of face black, keels brownish. Clypeus and adjacent part of frons brownish. Only one (weak) keel on transistion between vertex and frons. Dorsal half of genae black, ventral half brownish. Vertex and pronotum medially light-brown, laterally darker brownish. Mesonotum dark brown. Fore wings milky white, veins brownish, apically with very characteristic black markings.
Phallosoma ventrocaudally with a distinct ridge. One movable subapical spine on the right, two on the left side. Ventral process of anal tube almost symmetrical, roundish.

Distribution and ecology. Described from Mt. Narba (on meadows at the end of April, not very rare; Costa, 1888), endemic to Sardinia. The single record from continental Italy (Servadei, 1967) is erroneous (Holzinger, 2000). Ecology unknown.

\section{Simplicixius gen. n.}

Type species. Trirhacus trichophorus Melichar, 1914

Included species. Currently monospecific.

Etymology. The male genitalia are, compared to other Cixiini species, very simple. Gender: masculine.

Diagnosis. Phallosoma truncate, with a distinct lateral widening on the right side. Two short symmetrical processes at the distal end of the phallosoma, one slightly curved movable subapical spine on each side. Apical part of aedeagus in dorsal view distinctly s-shaped. Genital styles spoon-shaped, simple. Anal tube in males long and slender, ventral process smoothly rounded apically. Genital segment of female truncate, shaped like an inverse " $V$ ".

\section{Simplicixius trichophorus (Melichar, 1914) comb. n. (Figs 74-86) \\ Trirhacus trichophorus Melichar, 1914: 259}

Material studied. Lectotype of (Nast, 1965 design.), labelled (reddish-brown label) "Typus", (red label) "Lecto- / typus", "(handwritten) trichophorus / (printed) det. Melichar", "Nast 230", "Athos / Macedonien", in coll. HNHM Budapest.

$1 \delta 2$ 우, all labelled "Athos / Macedonien", (reddishbrown label) "Typus", "(handwritten) trichophorus / (printed) det. Melichar", (red label) "syn- / typus", Invent. Nr. 4258 (o), 4256 ( $($ ) and 4255 ( $($ ), in coll. MM Brno; 1 o labelled "Rodopi", "(Virgin-wood)", "Date 23.V.1983", "Leg. S. Drosopoulos", in coll. Drosopoulos, Athens.

Description. (see also Nast, 1965). Total length of male 5.7-6.2 mm, of female $6.3-6.6 \mathrm{~mm}$.

Vertex and frons dark brown, keels yellowish brown. Ventral part of face (clypeus and adjacent part of vertex) yellowish brown. Upper part of genae dark brown, ventral of antennae whitish to yellowish brown. Pronotum and mesonotum medially light brown, laterally darker. Fore wings hyaline with dark granulae and more or less distinct dark markings (Fig. 84).

Phallosoma tubular without teeth or keels, but with a distinct subapical widening on the right side. At its distal end two very short, symmetrical processes. Laterally, one evenly curved movable subapical spine on each side. Apical part of the aedeagus strongly bent when viewed from the side and above.

Distribution and ecology. Only known from the type locality (Athos, Greece), ecology unknown. 


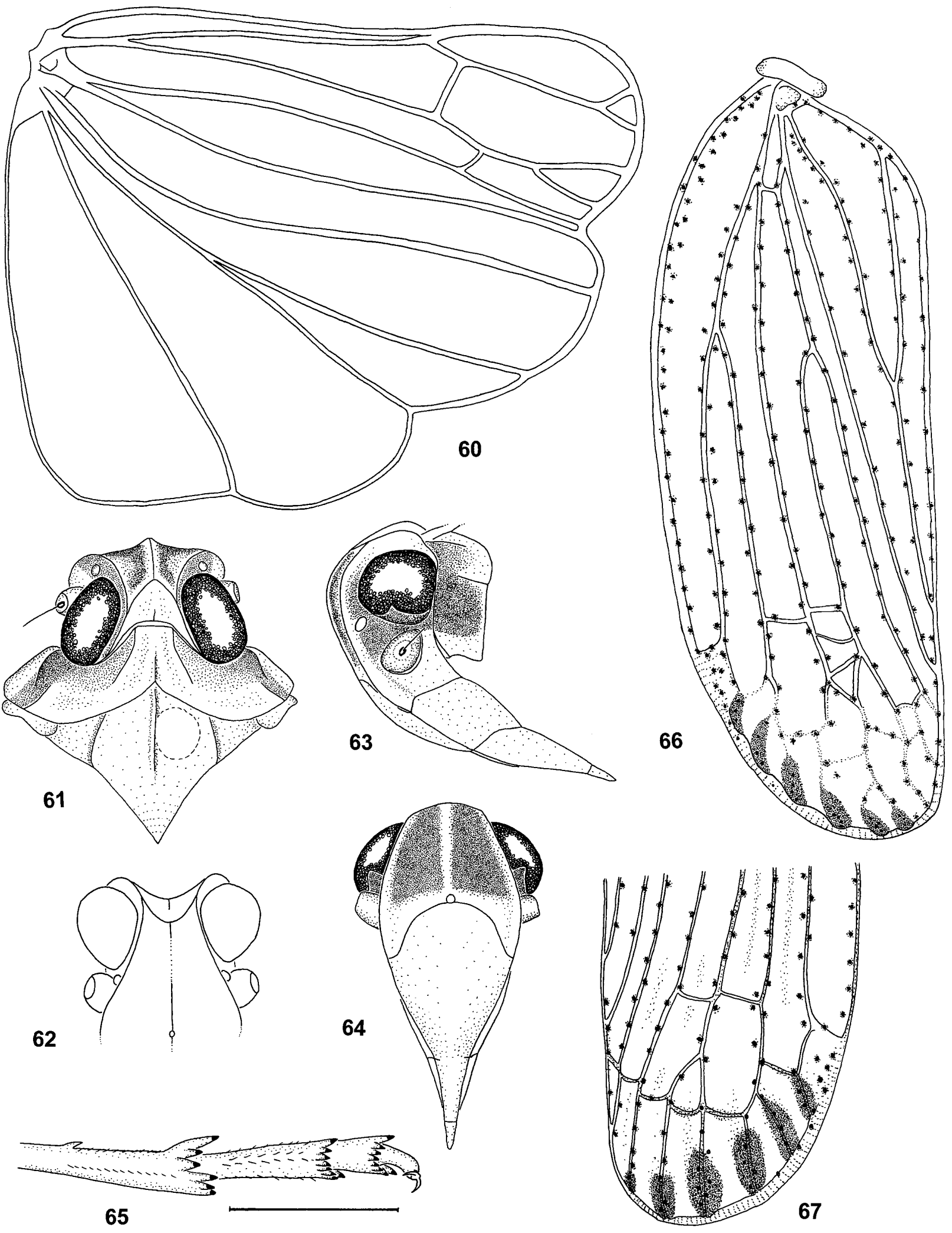

Figs 60-67. Sardocixius formosissimus (Costa, 1883). 60 - hind wing; 61 - head and thorax, dorsal view; 62-64 - head, frontal, lateral and ventral view; 65 - hind tarsus; 66 - fore wing of paratype; 67 - apical part of fore wing of lectotype. Scale bar $=1 \mathrm{~mm}$.

Sphaerocixius Wagner, 1939: 94 stat. nov.

Type species. Cixius (Sphaerocixius) globuliferus Wagner, 1939

Included species. Currently monospecific.
Diagnosis. Large species, habitus similar to Cixius, but with distinct autapomorphies in male genitalia: anal collar ventrally with a bulbous widening at the base; phallosoma with a doughnut-shaped process on the right side; base of apical part of the aedeagus has a bulbous widening ven- 


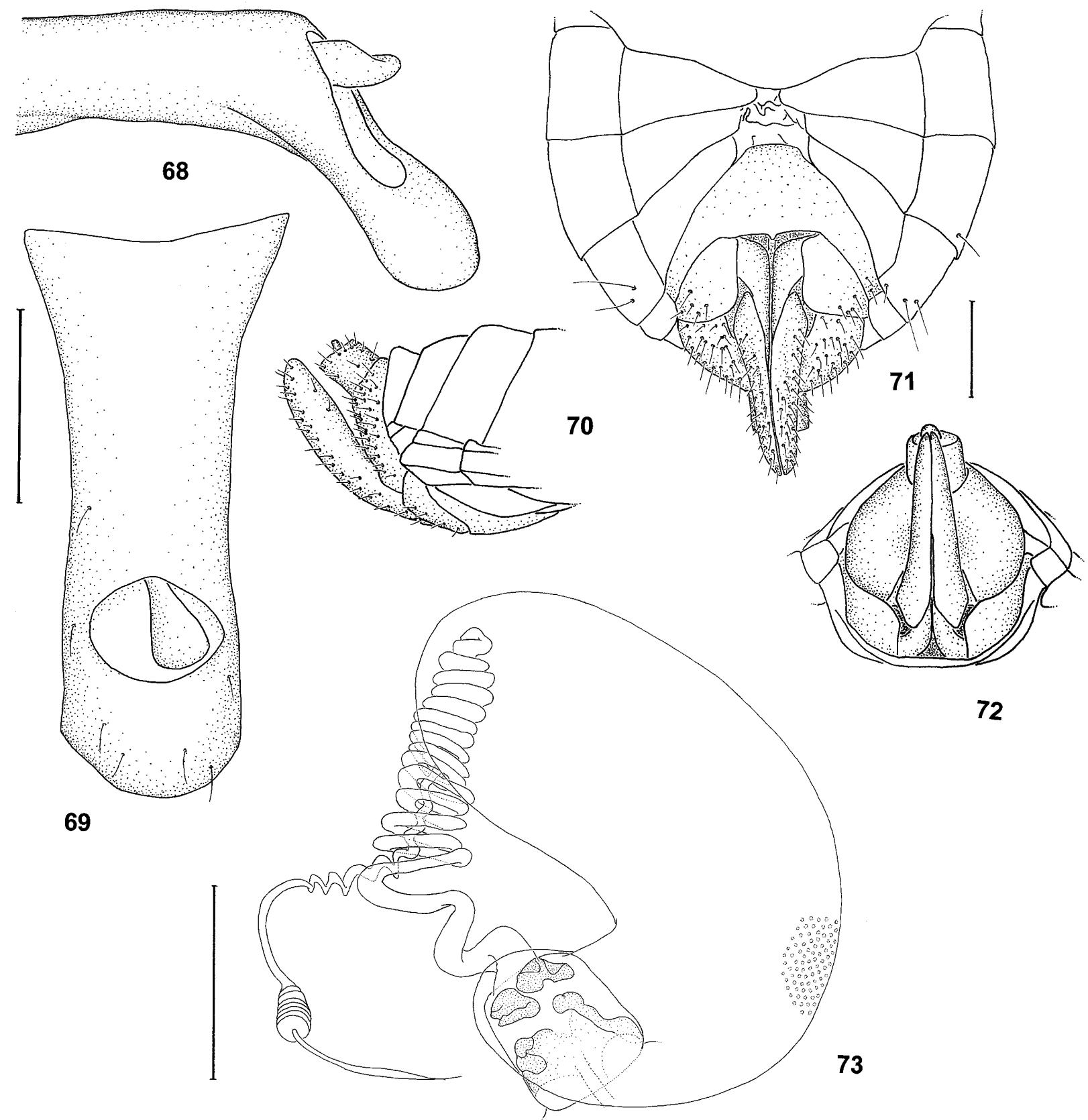

Figs 68-73. Sardocixius formosissimus (Costa, 1883). 68-69 - male anal segment, lateral and dorsal view; 70-72 - female abdomen, lateral, ventral and caudal view; $73-$ inner female genitalia. Scale bar $=0.5 \mathrm{~mm}$.

trally. End of female abdomen truncate, shaped like an inverse "V".

\section{Sphaerocixius globuliferus (Wagner, 1939) comb. n. (Figs 87-99)}

Cixius (Sphaerocixius) globuliferus Wagner, 1939: 94 (Figs 5, 11-15)

Neocixius globuliferus Wagner, 1948: 85

Trirhacus globuliferus Wagner, 1959: 586

Material studied. Holotype $\lesssim$, labelled "Meredita / M. Scheit", "Zeichnung / Nr. 66 / W. Wagner", (red label) "Holotype", "(handwritten) Sphaerocixius / globuliferus n. sp. / (printed) W. Wagner det. 1938", in coll. NHM Vienna.
2 oิ o 2 우, all labelled "Meredita / M. Scheit", "Paratype", "(handwritten) Sphaerocixius / globuliferus n. sp. / (printed) W. Wagner det. 1938", one male with an additional label "Zeichnung / Nr. 197 / W. Wagner", in coll. NHM Vienna.

Description. (See also Wagner, 1939) Total length of male $6.3-6.4 \mathrm{~mm}$, of female $6.7-6.9 \mathrm{~mm}$.

Frons dark brown, keels and clypeus lighter. Genae in upper part dark brown, ventrally lighter. Vertex medially dark brown, laterally lighter. Pronotum medially lightbrown, laterally dark-brown. Mesonotum dark-brown. Wings hyaline, dark markings as in Fig. 92.

Phallosoma with a long and slender movable subapical spine and a doughnut-shaped process on the right and a 

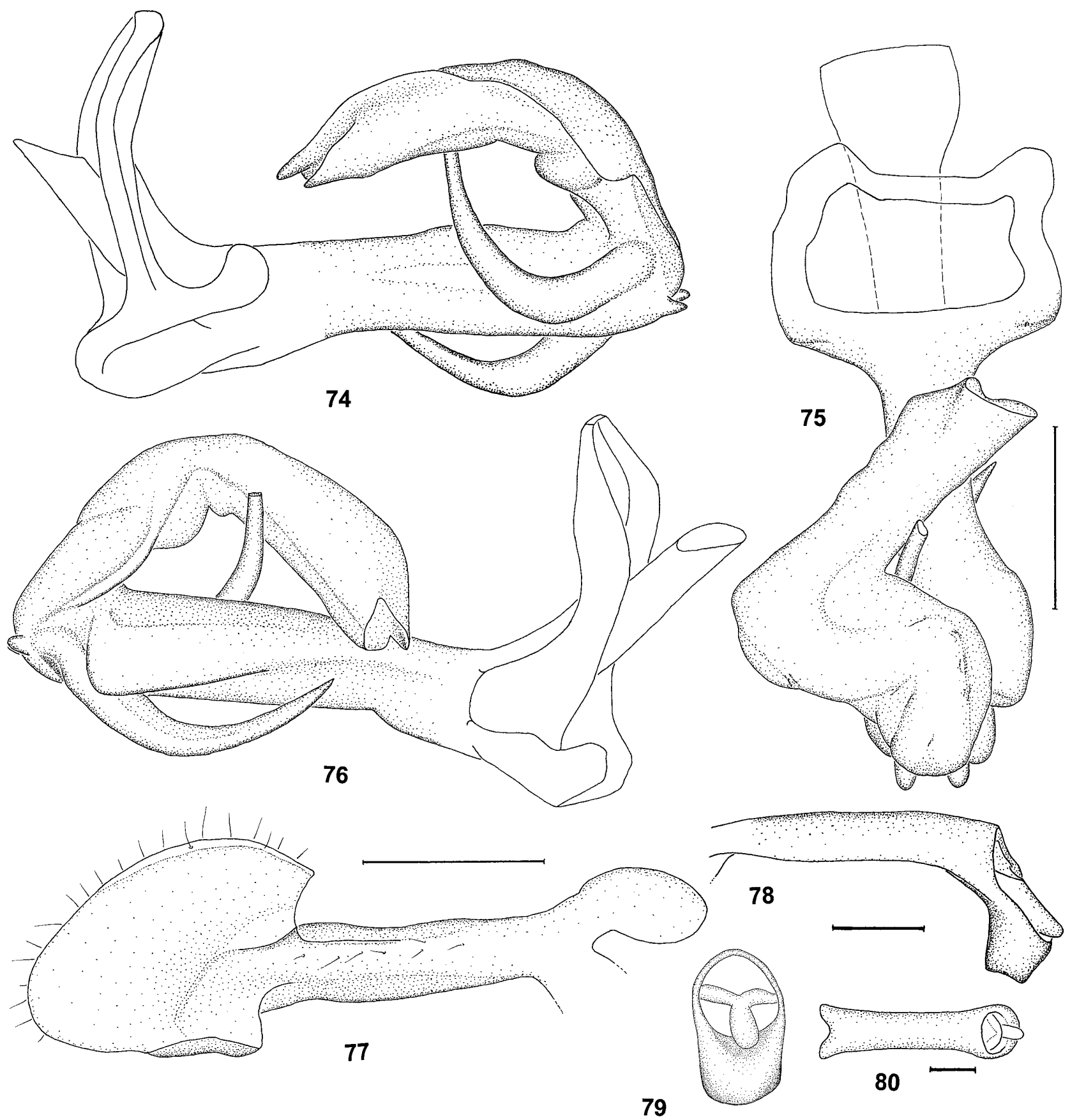

Figs 74-80. Simplicixius trichophorus (Melichar, 1914), male. 74-76 - aedeagus; 77 - genital style, inner maximum view; 78-80 - anal segment, lateral, caudal and dorsal view. Scale bar $=0.25 \mathrm{~mm}$.

broad movable subapical spine on the left side. Base of apical part of the aedeagus has a bulbous widening ventrally.

Distribution and ecology. Only known from Meredita Mts., Albania. Ecology unknown.

\section{Trirhacus Fieber, 1875: 354}

Type species. $T$. setulosus Fieber, 1876

Included species. $T$. setulosus Fieber, $T$. dubiosus Wagner, $T$. biokovensis Dlabola. The systematic position of T. iguchii Matsumura, 1914 is uncertain, but as it has a distinct wax plate, it is not belonging to Trirhacus (cf. Holzinger 1999 b).
Diagnosis. Fore wings ovoid, thus specimen ovalshaped. Abdomen of females truncate, without wax plate. Phallosoma ventrally has a rigid bifurcate process. Apical part of aedeagus with a large subapical process on the left side. Anal segment in males short and stout, apical process asymmetrical, bearing two large lobes.

Note. In T. dubiosus and T. biokovensis female specimens were unavailable. The placement in Trirhacus is preliminary; it is based on the above mentioned characters of the male genitalia. It must be remembered, that these characters are mainly of diagnostic importance; their homology and synapomorphy and, derived from that, phylogenetic value cannot be evaluated at this time. 


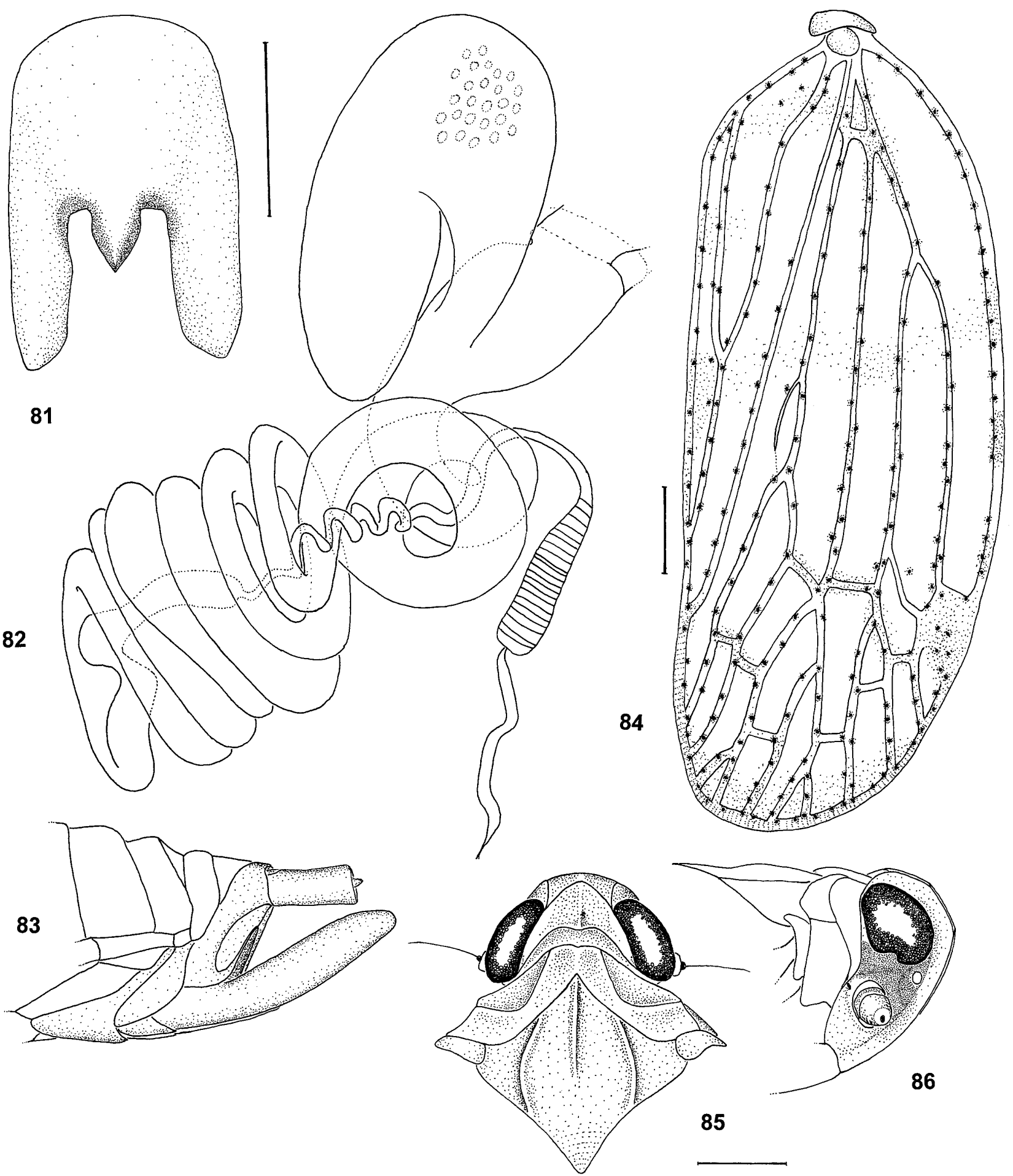

Figs 81-86. Simplicixius trichophorus (Melichar, 1914). 81 - male genital segment, ventral view; 82 - inner female genitalia; 83 female abdomen, lateral view; 84 - fore wing; 85 - head and thorax, dorsal view; 86 - head, lateral view. Scale bar $=0.5 \mathrm{~mm}$.

Distribution. Balkan peninsula.

\section{Trirhacus setulosus Fieber, 1876 (Figs 100-114)}

Trirhacus setulosus Fieber, 1876: 165

Material studied. Holotype $q$, labelled "Parnass / 9/5 65", "(handwritten) setulosus / det. Fieber", (red label) "Holotype", "(handwritten) Trirhacus setulosus", in coll. NHM Vienna.
1 q labelled "Parnass / 26/4 66", "(handwritten) setulosus / det. Fieber", in coll. NHM Vienna; 1 to 1 q labelled "Kephallenia / Paganetti", "(handwritten) Trirhacus o / setulosus Fieb. / J.Nast det. 1962", "Nast 272", in coll. HNHM Budapest; 1 \& labelled "Platanusa, Xerovuni / Epir., 700-800 m / 2.-12.VI.33, Beier", in coll. NHM Vienna. 


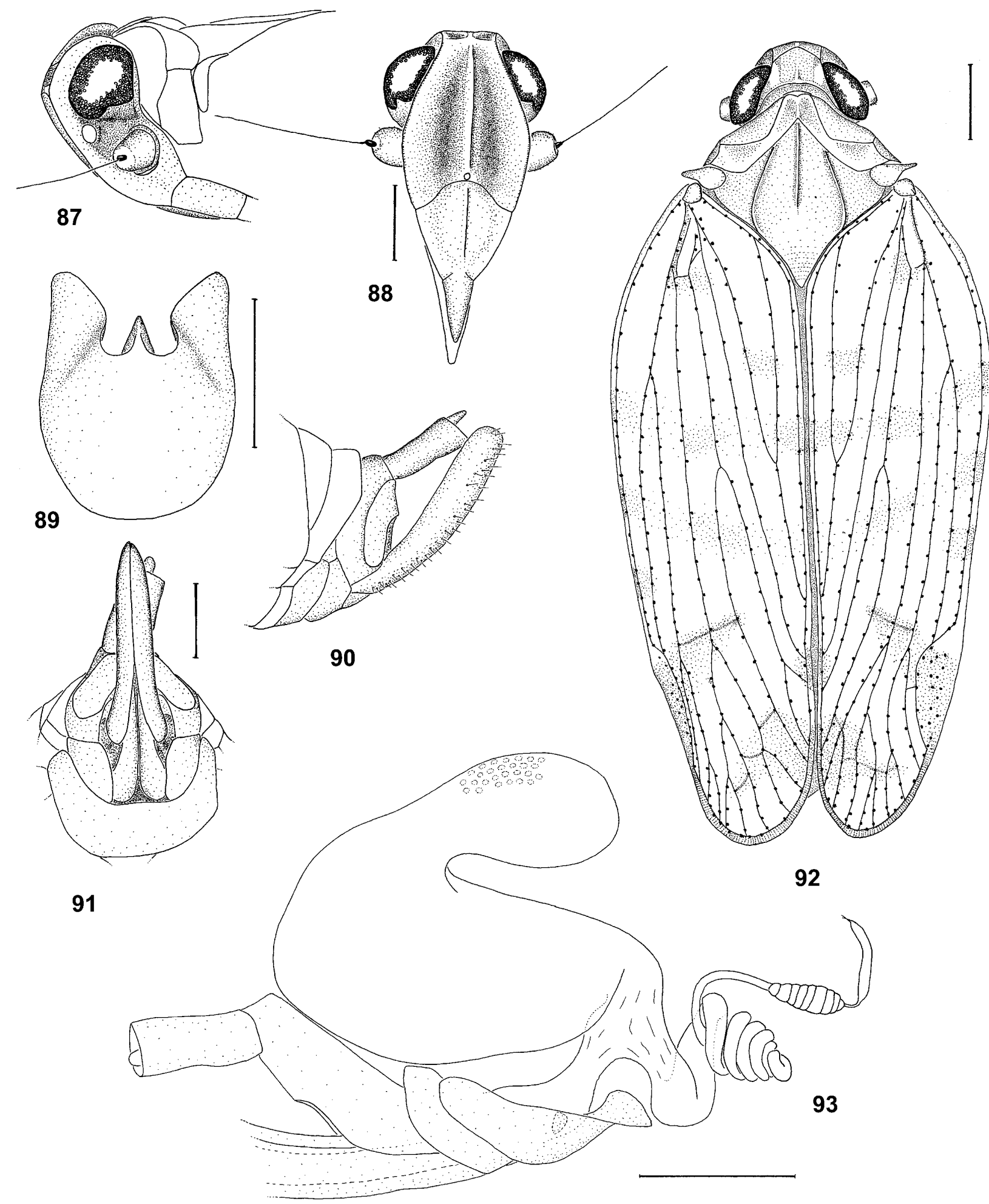

Figs 87-93. Sphaerocixius globuliferus (Wagner, 1939). 87-88 - head, lateral and frontal view; 89 - male genital segment, ventral view; 90-91 - female abdomen, lateral and ventral view; 92 - habitus, male; 93 - inner female genitalia. Scale bar $=0.5 \mathrm{~mm}$.

Description. (See also Nast, 1965) Total length of male $4.5 \mathrm{~mm}$, of female $5.2-5.6 \mathrm{~mm}$.

Head, pro- and mesonotum unicolorous brownish. Keels of pronotum slightly sexual dimorphic (see Figs 102 and 103). Fore wings hyaline with distinct dark markings (Fig. 104).
Phallosoma not elevated dorsally, but has distinct lateral widenings. Two short symmetrical processes at the distal end of the phallosoma. Phallosoma has one straight, movable subapical spine on each side. Ventrally a slightly s-shaped, forked, rigid process is present. Apical part of 


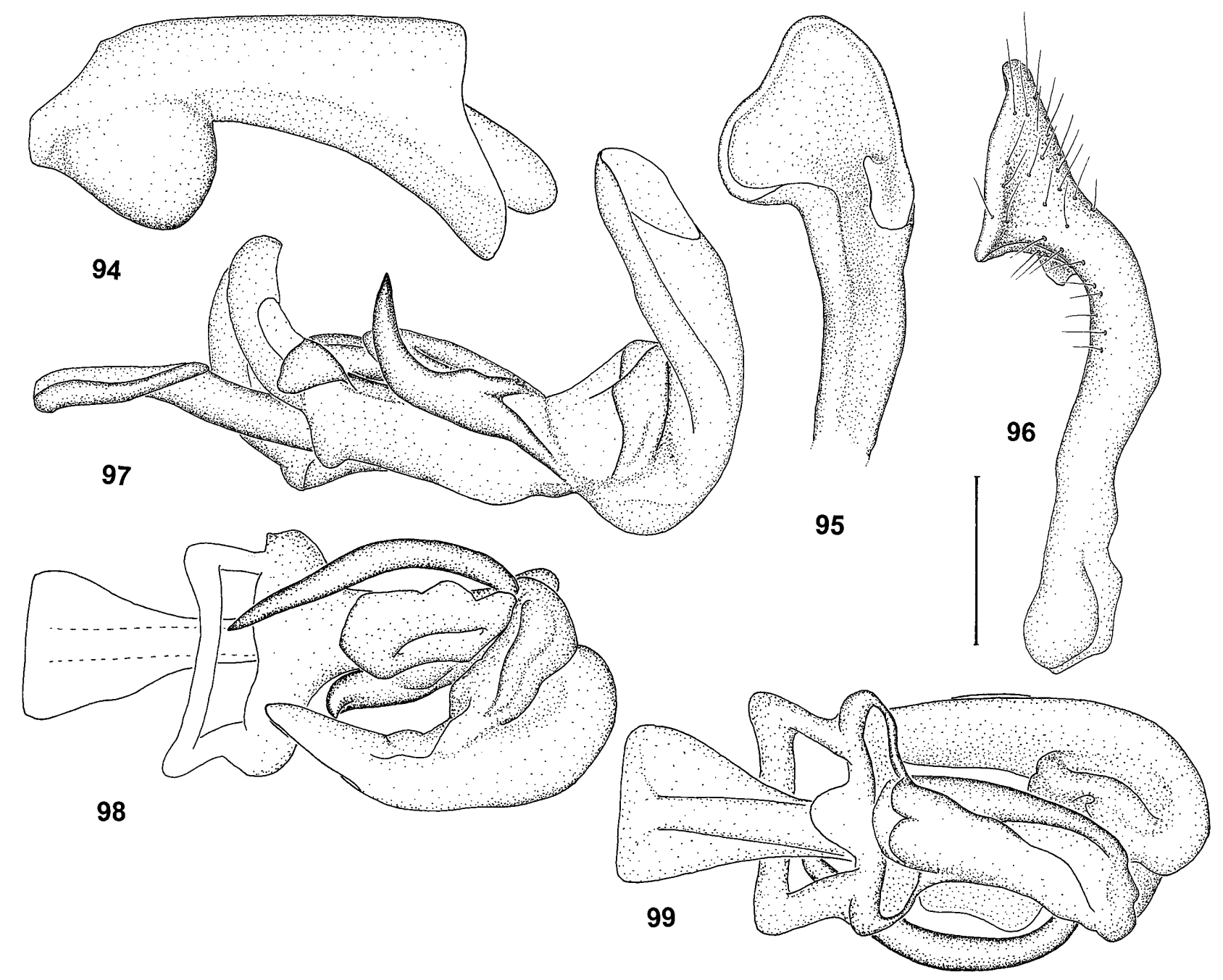

Figs 94-99. Sphaerocixius globuliferus (Wagner, 1939), male. 94 - anal segment; 95 - right genital style, inner maximum view; 96 - left genital style, lateral view; 97-99 - aedeagus. Scale bar $=0.2 \mathrm{~mm}$.

aedeagus slightly curved, with a distinct, long and thin subapical spine on the left side.

Female abdomen truncate, evenly rounded, without wax plate. Ductus ejaculatorius with four windings.

Distribution and ecology. T. setulosus is restricted to Greece (Fieber, 1876: 166 "Parnasse"; Wagner, 1959: 584 "Kephallinia, Aenos and Platanusa, Xerovuni") and perhaps former Yugoslavia (Nast, 1972, 1987; no localities or references given), the records of T. setulosus from Spain (Melichar, 1907) and Italy (Servadei, 1967) are based on misidentifications.

Specimens were collected between end of April and mid of June. Habitat and host plants are unknown.

\section{Trirhacus biokovensis Dlabola, 1971 (Figs 115-125)}

Trigonocranus emmae sensu Dlabola, 1958: 10 nec Fieber, 1876

Trirhacus biokovensis Dlabola, 1971: 130

Material studied. 1 ô labelled "Dalmatia / Novak", (red label) "Paratypus / (handwritten) Trirhacus / biokovensis đ n. sp. / det. Dlabola 1971", in coll. Holzinger.

Description. (See also Dlabola 1958, 1971) Total length of male $4.5 \mathrm{~mm}$, female $5.4 \mathrm{~mm}$ (according to Dlabola, 1971)
Face, vertex, pro- and mesonotum brownish, keels lighter. Fore wings hyaline with dark markings as in Fig. 123.

Ventral side of phallosoma with a very large process (Figs 116, 117). One small and two large movable subapical spines present on the right and one on the left side of the phallosoma. Apical part of aedeagus strongly bent, with a large median process on the left side.

Distribution and ecology. Only known from the type locality (Biokovo Mts., Dalmatia, Croatia; in $1.200 \mathrm{~m}$ a.s.l.), collected May $1^{\text {st }}, 1952$ and June $15^{\text {th }}, 1955$ on Cornus nigra (Dlabola, 1958, 1971).

Trirhacus dubiosus Wagner, 1959 (Figs 126-134)

Trirhacus dubiosus Wagner, 1959: 584

Material studied. Holotype ô, labelled "Vaganj / Prolog Bos. / Novak 29.6-40", (red label) "Holotype", "(handwritten) Trirhacus / dubiosus n. sp./ (printed) W. Wagner det. 1959”, in coll. NHM Vienna.

Description. (See also Wagner, 1959) Total length of male $4.8 \mathrm{~mm}$. 

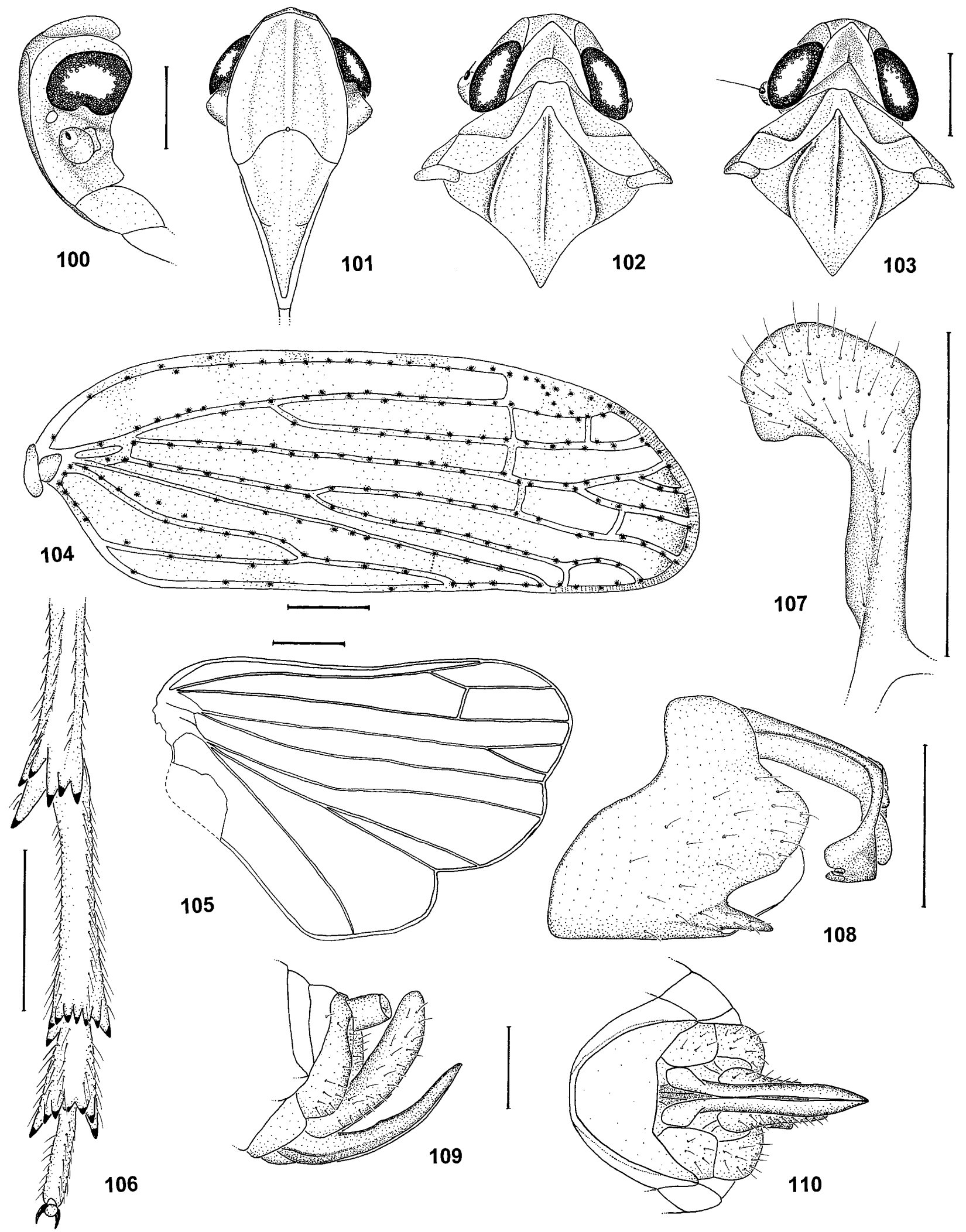

Figs 100-110. Trirhacus setulosus Fieber, 1876. 100-101 - head of holotype (female), lateral and frontal view; 102 - head and thorax of holotyle (female), dorsal view; 103 - head and thorax of male specimen; 104 - fore wing; 105 - hind wing; 106 - hind tarsus; 107 - male genital style; 108 - male genital and anal segment, ventrolateral view; 109-110 - female abdomen, lateral and ventral view. Scale bar $=0.5 \mathrm{~mm}$.

Head, pro- and mesonotum more or less unicolorous brownish. Fore wings hyaline with brownish granulae and some dark markings. 


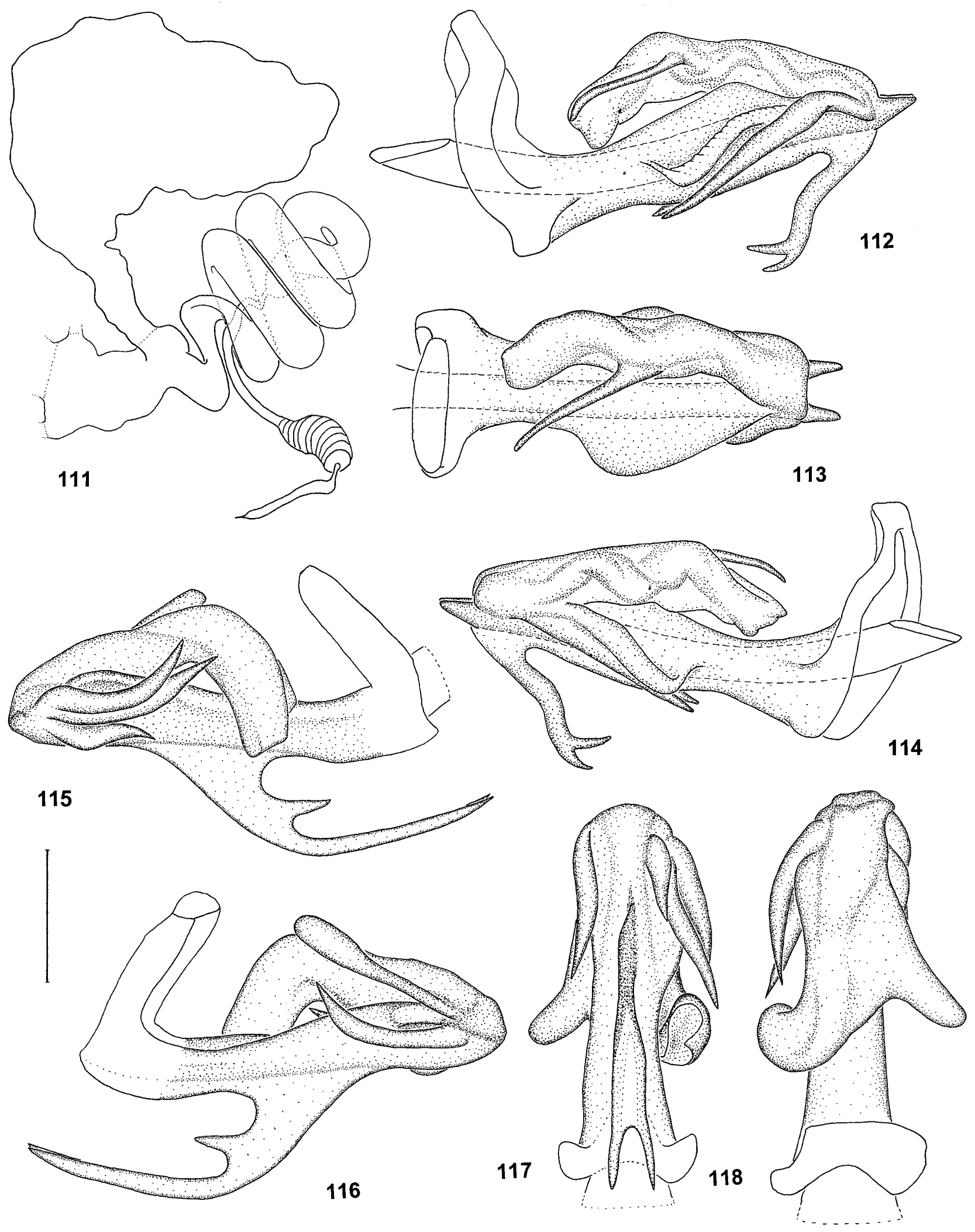

Figs 111-114. Trirhacus setulosus Fieber, 1876. $111-$ Inner female genitalia; 112-114 - aedeagus. Scale bar $=0.2 \mathrm{~mm}$. Figs 115-118. Trirhacus biokovensis Dlabola, 1971, aedeagus. Scale bar $=0.2 \mathrm{~mm}$.

Phallosoma with a distinct ventral keel ending in two slender processes. Dorsally another keel is present on the left side. Two curved, slender movable apical spines on the right, and one on the left side. Left side of the apical part of the aedeagus has a broad process basally. 


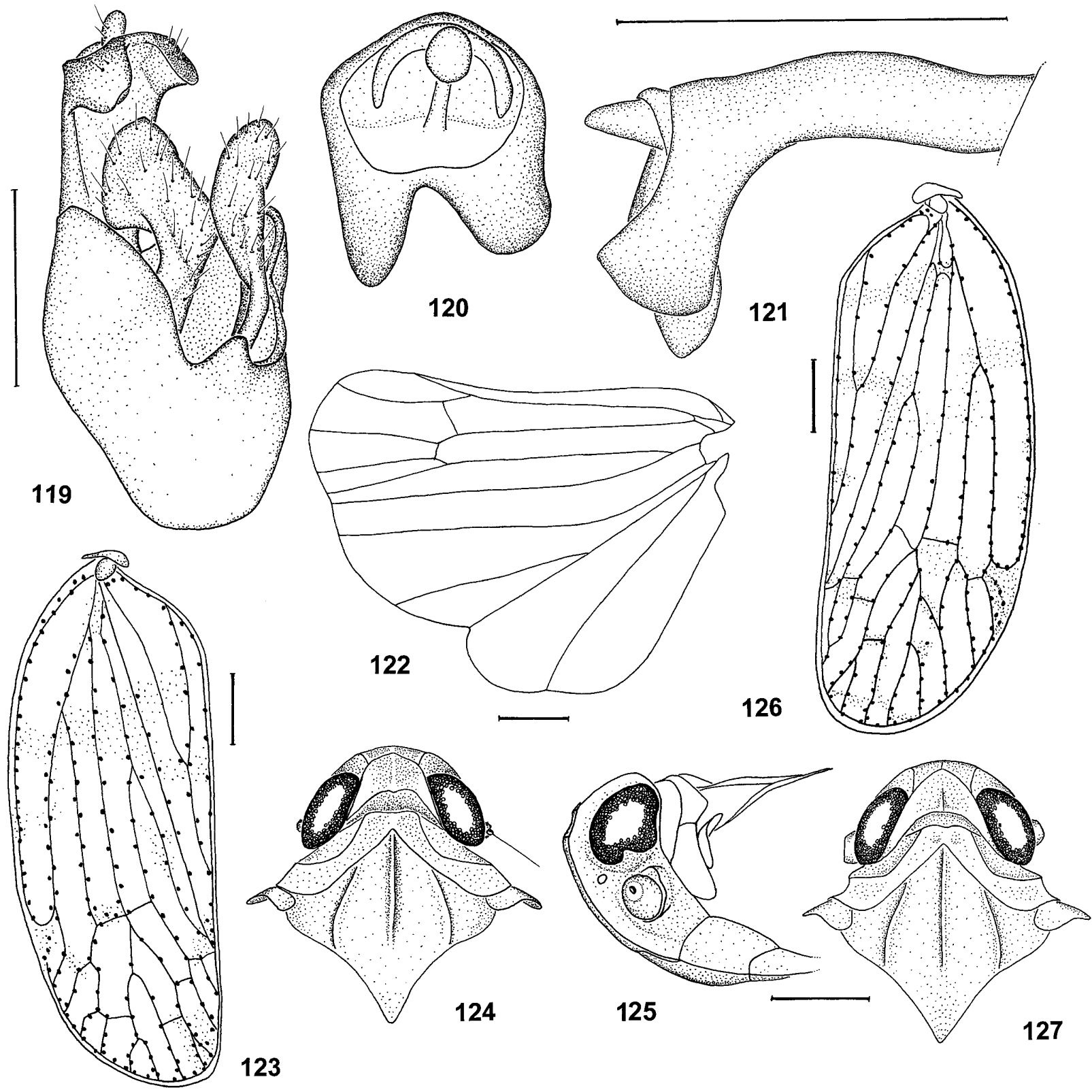

Figs 119-125. Trirhacus biokovensis Dlabola, 1971. 119 - genital segment, genital styles and anal segment, ventrolateral view; 120-121 - anal segment, caudal and lateral view; 122 - hind wing; 123 - fore wing; 124 - head and thorax, dorsal view; 125 - head, lateral view. Scale bar $=0.5 \mathrm{~mm}$.

Figs 126-127. Trirhacus dubiosus Wagner, 1959. 126 - fore wing; 127 - head and thorax, dorsal view. Scale bar $=0.5 \mathrm{~mm}$.

Distribution and ecology. Only known from the type locality ("Vipera, Dalmatien"; Monte Vipera is a former Italian name of Sv. Ilija on the peninsula Peljesac SE Split, NE Dubrovnik, Croatia), ecology unknown.

\section{Trirhacus peloponnesiacus sp. n. (Figs 135-146)}

The male was discovered among unidentified specimens in the Moravian Museum in Brno. One additional female collected by Prof. Sakis Drosopoulos in the same locality is obviously conspecific.

Material studied. Holotype $\delta$, labelled "GraeciaPelopones / Teygetos Mt. $1700 \mathrm{~m} /$ Artemissia 5.5.79/ Hladilovi lgt", "Collectio / P. Lauterer / Mor. museum, Brno", in coll. MM Brno, and 1 q paratype, labelled
"Taygetos Mt. (700-1300 m) / (above Artemisia) / Date 30.IV.1985 / leg. S. Drosopoulos", in coll. Drosopoulos, Athens.

Etymology. The name is derived from the peninsula where the specimens were collected.

Description and differential diagnosis. Total length of male $4.3 \mathrm{~mm}$, of female $4.8 \mathrm{~mm}$.

Head, pro- and mesonotum uniform brownish, keels yellowish. As in T. setulosus, the shape of the fore keel of the pronotum is slightly different in males and females. Fore wings very similar to $T$. setulosus: ovoid, hyaline, with irregular dark markings mainly near the veins, apical parts of apical cells brownish. 


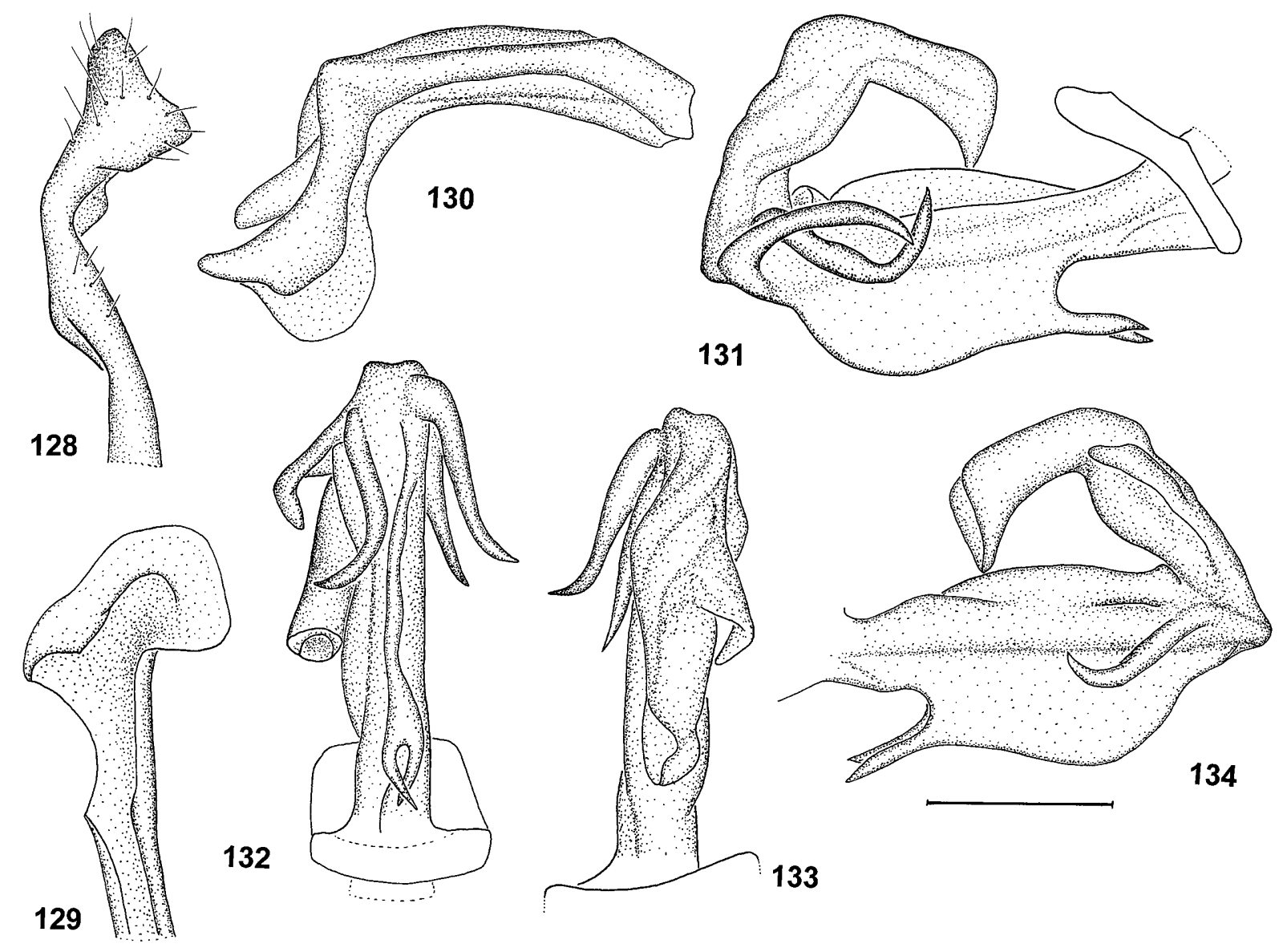

Figs 128-134. Trirhacus dubiosus Wagner, 1959. 128-129 - genital style; 130 - anal segment, lateral view; 131-134 - aedeagus. Scale bar $=0.2 \mathrm{~mm}$.

Phallosoma has ventrally a thorny crest strongly bent towards the right side, dorsally has a whitish widening on the left side. Two movable subapical spines are present: a shorter, slightly bent one on the right and a very long, curved one on the left side (see Figs 143-146). Apical part of aedeagus on the left side with a broad, flat, basally pointed process. Anal segment asymmetrical, short and stout, apical process ending in two acute lobes (Figs 138-140).

The helix of the ductus receptaculi in the female has more inner and outer windings than the (only one dissected) female of T. setulosus. (Fig. 146).

This species is slightly smaller than the other species of Trirhacus. It can be distinguished from these and other Cixiidae by the unique shape of the aedeagus, as described above and shown in Figs 142-145.

Distribution and ecology. Only known from the type locality, Taygetos Mts., on Peloponnesos Peninsula, Greece. Ecology unknown.

ACKNOWLEDGEMENTS. I am very much indebted to Dr. M. Asche (Berlin) for critical comments on the manuscript. Furthermore, I am grateful to Dr. T. Bourgoin (Paris) and I. Kammerlander (Graz) for additional very interesting comments, to Prof. Dr. A. Emeljanov (St. Petersburg) for important information on the key, Dr. Alan Stewart (Sussex) for linguistic help, and to Prof. Dr. A. Arzone (Torino), Dr. M. Asche and Prof. Dr. H.
Hoch (Berlin), Dr. T. Bourgoin (MNHN Paris), Dr. J. Dlabola (Praha), Dr. H. Duffels (Museum Amsterdam), Prof. Dr. S. Drosopoulos (Athens), Dr. P. Lauterer (MM Brno), Mr. A. Orosz (HNHM Budapest), Mr. M. Webb (NHM London) and Dr. H. Zettel (NHM Vienna) for the loan of material. Furthermore, I wish to thank Dr. E. Stabentheiner (Universität Graz, Institut für Pflanzenphysiologie) for the SEM pictures. This work was financed by an APART grant from the Austrian Academy of Science.

\section{REFERENCES}

Bourgorn T. 1993: Female genitalia in Hemiptera Fulgoromorpha, morphological and phylogenetic data. Ann. Soc. Entomol. Fr. (N. S.) 29: 225-244.

CAstellani O. 1953: Contributo alla conoscenza della fauna Emitterologica d'Italia. Hemiptera Homoptera II. Boll. Ass. Rom. Entomol. 8: 1-11.

Costa A. 1883: Diagnosi di nuovi Artropodi trovati in Sardegna. Boll. Soc. Entomol. Ital. 15: 332-341.

Costa A. 1888: Notizie ed osservazioni sulla geofauna sarda Mem. II, Risultamento di ricerche fatte in Sardegna nella primavera del 1882. Atti dell'Accad. Sci. Fis. Mat. Napoli 1: $1-111$.

Dlabola J. 1958: Records of leafhoppers from Czechoslovakia and south european countries (Homoptera: Auchenorrhyncha). Acta Faun. Entomol. Mus. Nat. Pragae 3: 7-15.

Dlabola J. 1971: Taxonomische und chorologische Ergänzungen zur türkischen und iranischen Zikadenfauna (Homop- 

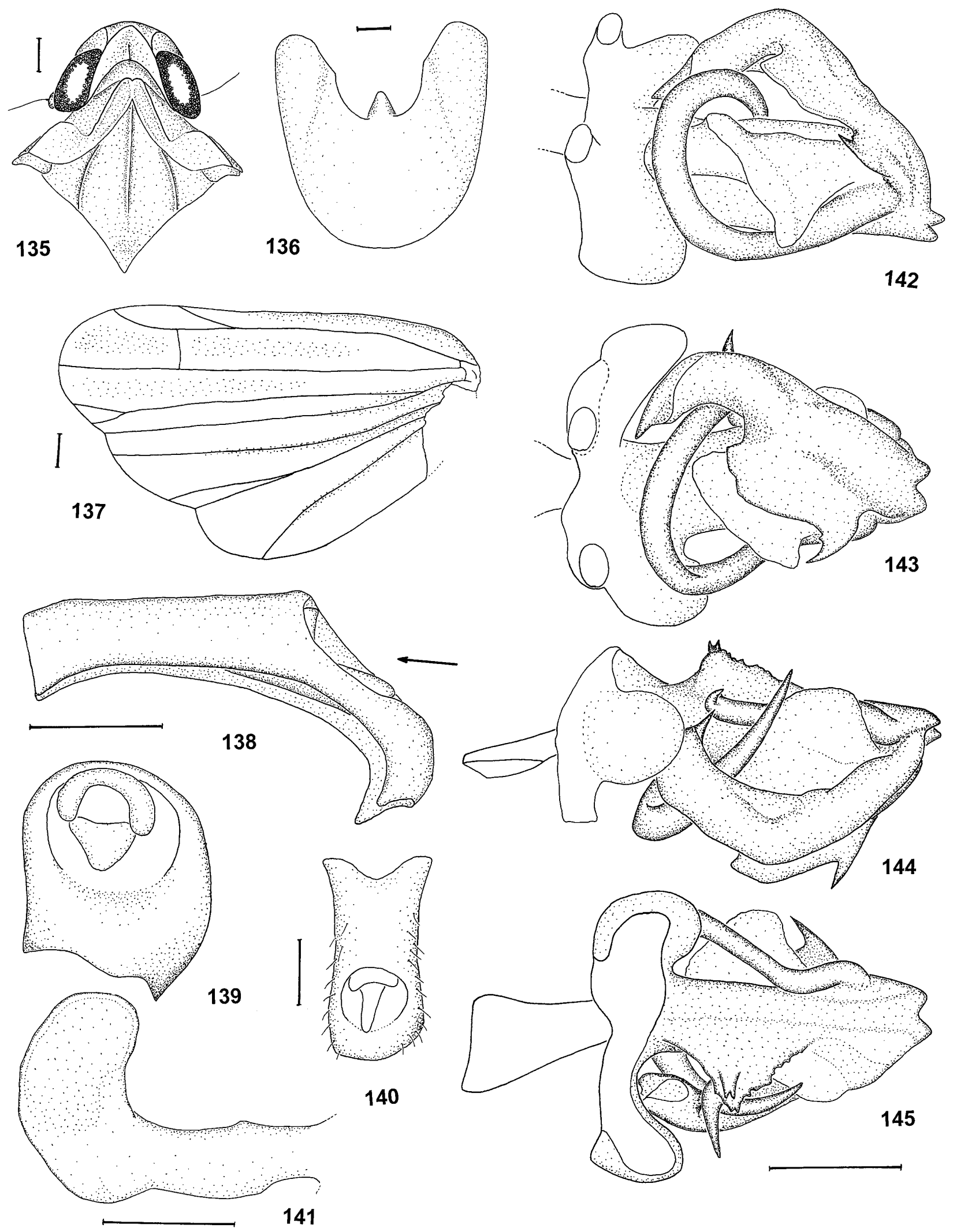

Figs 135-145. Trirhacus peloponnesiacus sp. n., holotype male. 135 - head and thorax, dorsal view; 136 - genital segment; 137 hind wing; 138-140 - anal segment, lateral, caudal (in direction of the arrow in Fig. 138) and dorsal view; 141 - genital style; $142-145-$ aedeagus. Scale bar $=0.2 \mathrm{~mm}$. 


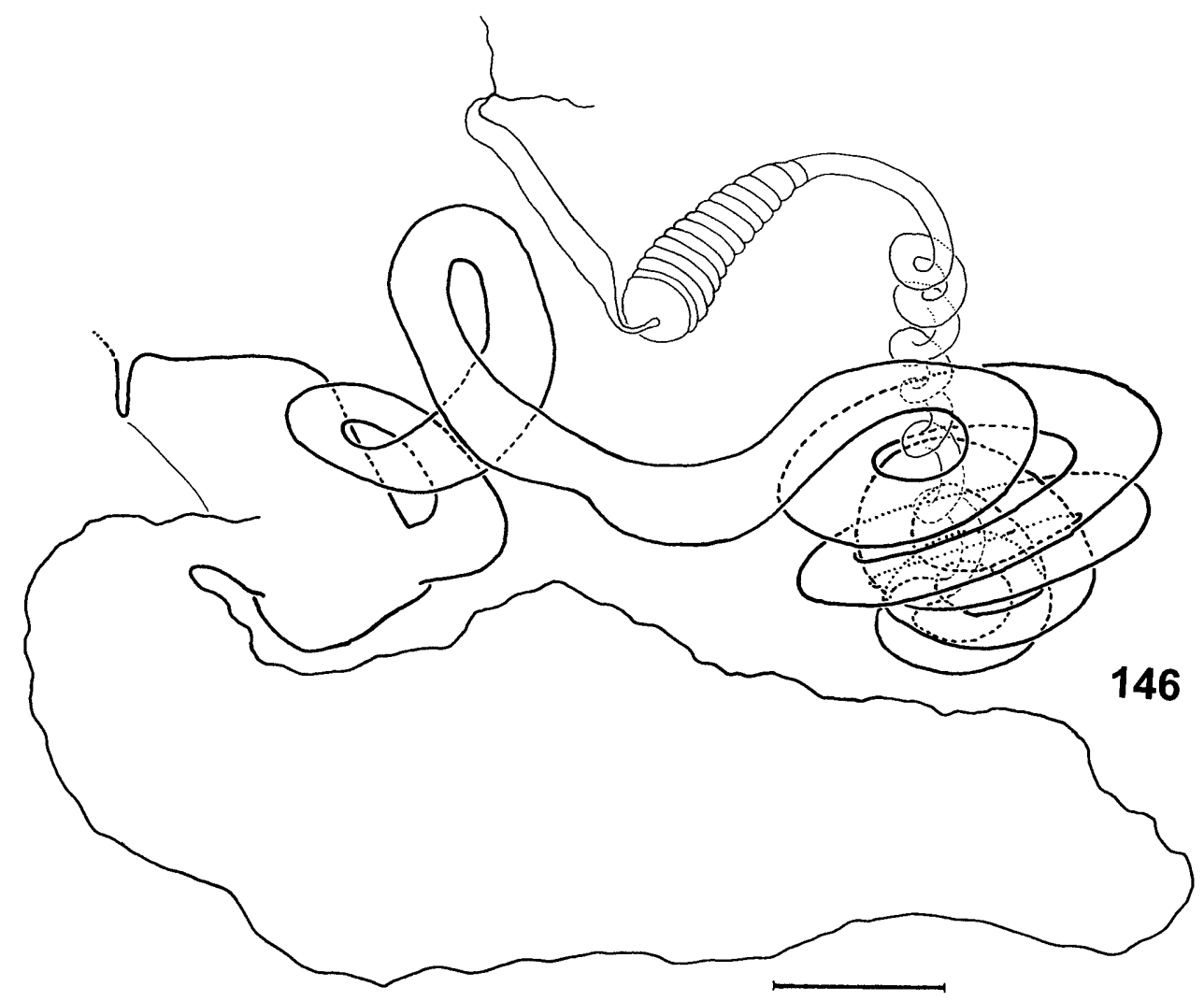

Fig. 146. Trirhacus peloponnesiacus sp. n., female: Ductus receptaculi and bursa copulatrix. Scale bar $=0.25 \mathrm{~mm}$.

tera: Auchenorrhyncha). Acta Faun. Entomol. Mus. Nat. Pragae 14: 115-138.

Dlabola J. 1977: Chorologische Ergänzungen zur Zikadenfauna des Mittelmeergebietes (Homoptera: Auchenorrhyncha). Acta Mus. Nat. Pragae 33 B: 21-40.

Dlabola J. 1980: Neue Zikadenarten der Gattung Siculus gen n., Mycterodus und Adarrus aus Südeuropa und 6 neue Mycterodus aus Iran (Homoptera: Auchenorrhyncha). Acta Faun. Entomol. Mus. Nat. Pragae 16: 55-71.

Dlabola J. 1988: Reklassifikation der Gattungen der Pentastirini und neue Taxone der Cixiidae (Homoptera: Auchenorrhyncha). Acta Entomol. Bohemoslov. 35: 49-70.

D’URso V. 1995: Homoptera Auchenorrhyncha. In: Minelli A., Ruffo S. \& La Posta S. (eds): Checklist delle Specie della Fauna Italiana 42: 1-35.

FIEBER F.X. 1875: Les Cicadines d'Europe d'après les originaux et les publications les plus récentes. Premiére partie: Comprenant les familles des Membracida, Cicadaea, Fulgorida, Cercopida, Ulopida, Paropida, Scarida, disposées selon la méthode analytique. Rev. Mag. Zool. 1875: 288-416.

FIEBER F.X. 1876: Les Cicadines d'Europe d'après les originaux et les publications les plus récentes. Deuxième partie: Description des espèces. Rev. Mag. Zool. 1876: 1-258.

Hoch H. 1994: Homoptera (Auchenorrhyncha: Fulgoroidea). In: Juberthie C. \& Decu V. (eds) Encyclopaedia Biospeologica, Tome I, pp. 313-325.

Носн H. \& Asche M. 1993: Evolution and speciation of cavedwelling Fulgoroidea in the Canary Islands (Homoptera: Cixiidae \& Meenoplidae). Zool. J. Linn. Soc. 109: 53-101.

Hoch H. \& Howarth F.G. 1989a: Reductive evolutionary trends in two new cavernicolous species of a new Australian cixiid genus (Homoptera: Fulgoroidea). Syst. Entomol. 14: 179-196.
Hoch H. \& Howarth F.G. 1989b: Six new cavernicolous cixiid planthoppers in the genus Solonaima from Australia (Homoptera: Fulgoroidea). Syst. Entomol. 14: 377-402.

HolzingER W.E. 1999a: Morphologie, Verbreitung und Bionomie von Trirhacus michalki (Wagner, 1948) (Insecta: Hemiptera: Auchenorrhyncha: Cixiidae). Senckenbergiana biol. 78: 153-159.

Holzinger W.E. 1999b: On three species of the planthopper genera Cixius and Trirhacus in the eastern Palaearctic Region (Hemiptera: Auchenorrhyncha: Fulgoromorpha: Cixiidae). Reichenbachia 33: 13-19.

HolzingER W.E. 2000: Tachycixius arzonei sp. n., a new planthopper species from Italy (Insecta: Hemiptera: Fulgoromorpha: Cixiidae). Linzer Biol. Beitr. 32: 1269-1274.

Holzinger W.E., Emeljanov A.F. \& Kammerlander I. 2002: The family Cixiidae Spinola, 1839 (Hemiptera: Fulgoromorpha) - a review. Denisia 4: 113-138.

LaRIVIÈre M.-C. 1999: Cixiidae (Insecta: Hemiptera: Auchenorrhyncha). Fauna of New Zealand 40: 1-93.

Melichar L. 1907: Bericht über die mit Subvention der kaiserl. Akademie der Wissenschaften unternommene entomologische Studienreise nach Spanien und Marokko. Österr. Akad. Wiss., Sber. Math.-Naturwiss. Kl., Abt. I 116: 1025-1039.

Melichar L. 1914: Neue paläarktische Homopteren. Wiener Entomol. Z. 33: 259-260.

Nast J. 1965: On the Genus Trirhacus Fieb. (Homoptera: Cixiidae). Zool. Beitr., N. F. 11: 183-189.

NASt J. 1972: Palaearctic Auchenorrhyncha (Homoptera). An annotated check list. Polish scientific publishers, Warszawa, $551 \mathrm{pp}$.

NASt J. 1987: The Auchenorrhyncha (Homoptera) of Europe. Ann. Zool. 40: 535-661. 
Remane R. \& Holzinger W.E. 1998: Zwei neue Cixius (Ceratocixius)-Arten aus der Südwestpalaearktis (Insecta: Auchenorrhyncha: Cixiidae). Reichenbachia 32: 181-186.

RiBaut H. 1958: Liste des espèces francaises des genres Cixius, Tachycixius, Neocixius et description de Tachycixius pyrenaicus (Fieb.) (Homoptera: Cixiidae). Bull. Soc. Hist. Nat. Toulouse 93: 483-488.

SeRVAder A. 1967: Rhynchota (Heteroptera, Homoptera Auchenorrhyncha). Fauna d'Italia 9, Calderini, Bologna, $851 \mathrm{pp}$.

Tsaur S.-C., Hsu T.-C. \& Van Stalle J. 1988: Cixiidae of Taiwan, Part (I) Pentastirini. J. Taiwan Mus. 41: 35-74.

Tsaur S.-C., Hsu T.-C. \& Van Stalle J. 1991: Cixiidae of Taiwan, Part VI. Cixius. J. Taiwan Mus. 44: 169-306.
VIlbaste J. 1968: Über die Zikadenfauna des Primorje Gebietes. Tallinn, 179 pp. [in Russian]

WAGNeR W. 1939: Die Zikaden des Mainzer Beckens. Jb. Nassauer Ver. Naturkunde Wiesbaden 86: 77-212.

WAGNER W. 1948: Neue deutsche Homopteren und Bemerkungen über schon bekannte Arten. Verh. Naturwiss. Ver. Heimatforschung Hamburg 29: 72-89.

WAGNER W. 1959: Zoologische Studien in Westgriechenland, IX. Teil: Homoptera. Österr. Akad. Wiss., Sber. Math.-Naturwiss. Kl., Abt. I 168: 581-605.

Received August 20, 2001; revised February 6, 2002; accepted March 4, 2002 